\title{
Linking bio-oceanography and population genetics to assess larval connectivity
}

\author{
G. Soria ${ }^{1,2, *}$, A. Munguía-Vega ${ }^{1,3}$, S. G. Marinone ${ }^{4}$, M. Moreno-Báez ${ }^{1}$, \\ I. Martínez-Tovar ${ }^{5}$, R. Cudney-Bueno ${ }^{1,6}$ \\ ${ }^{1}$ School of Natural Resources and the Environment, University of Arizona, Tucson, Arizona 85721, USA \\ ${ }^{2}$ Centro Nacional Patagónico, Boulevard Brown 2915, U9120ACD, Puerto Madryn, Chubut, Argentina \\ ${ }^{3}$ Comunidad y Biodiversidad A. C., Colonia Centro, La Paz, Baja California Sur, Mexico \\ ${ }^{4}$ Departamento de Oceanografía Física, Centro de Investigación Científica y de Educación Superior de Ensenada, Ensenada, \\ Baja California, Mexico \\ ${ }^{5}$ Centro Intercultural de Estudios de Desiertos y Océanos (CEDO), Puerto Peñasco, Sonora 83550, Mexico \\ ${ }^{6}$ Institute of Marine Sciences, University of California Santa Cruz, Santa Cruz, California 95060, USA
}

\begin{abstract}
Marine reserves (areas closed to fishing) have been advocated for the management of many species, including the rock scallop Spondylus calcifer in the northern Gulf of California (NGC), Mexico. We developed an explicit coupled biological-oceanographic model (CBOM) to assess connectivity among fished subpopulations of $S$. calcifer. We focused on the Puerto Peñasco corridor, located in the northeastern portion of the NGC. We validated CBOM's outputs through 2 different techniques: population genetics with 9 microsatellite loci and measurements of spat abundance on artificial collectors. We found strong demographic connectivity between the corridor and southern sources. Sampled localities showed low levels of genetic structure; however, we identified 2 subtly differentiated genetic clusters. On average, the spatial scale of demographic and genetic connectivity is in agreement, suggesting that connectivity decreases when the spatial scale is $>100 \mathrm{~km}$. We observed a gradient of higher values of both predicted particles and observed densities of settled spat for the northern and southern sites and lower values for the central sites. Larval recruitment within the corridor could be linked to a large spatial scale of larval inputs, including local sources and subpopulations further south. The absence of a strong barrier to migration suggests that the siting of marine reserves along upstream sites would likely benefit downstream subpopulations. The spatial scale of connectivity $(\sim 100 \mathrm{~km})$ could be used as a reference for the strategic siting of marine reserves in the study area. CBOMs and population genetics are powerful complementary tools to assess the relative strength of connectivity among sites.
\end{abstract}

KEY WORDS: Spondylus calcifer $\cdot$ Larval dispersal $\cdot$ Genetic structure $\cdot$ Marine reserves $\cdot$ Gulf of California

Resale or republication not permitted without written consent of the publisher

\section{INTRODUCTION}

The establishment of marine reserves (areas closed to fishing) is a promising tool for fisheries management and conservation of ecosystems and biodiversity (Crowder et al. 2000, Jones et al. 2007). However, siting marine reserves is a complex task which involves biological, physical and anthropogenic factors such as fishing pressure (Crowder et al. 2000, Pollnac et al. 2010). The positive effects of spatial management tools, such as marine reserves, on recovery of exploited stocks have been documented world-wide (Gell \& Roberts 2003, Lester et al. 2009, Aburto-Oropeza et al. 2011), particularly in sessile or sedentary stocks (Lester et al. 2009). For mobile species, adjacent fished areas might benefit from density-dependent spillover (Gell \& Roberts 2003, Hilborn et al. 2004), whereas both mobile and sedentary species may benefit from enhanced recruitment through larval dispersal from protected spawning 
grounds (Gell \& Roberts 2003, Beukers-Stewart et al. 2005, Cudney-Bueno et al. 2009, Pelc et al. 2009).

Benthic bivalve species are structured in metapopulations in which separate subpopulations of sessile juveniles and adults are connected through larval dispersal (Lipcius et al. 2005, Orensanz et al. 2006). The extent to which these subpopulations are linked by the exchange of larvae is termed connectivity and can have multiple and different patterns (Palumbi 2003, Orensanz et al. 2006). Thus, effective design and implementation of marine reserves requires knowledge about the spatial and temporal dynamics of biological connectivity between subpopulations, particularly those that are sources of larvae that can populate other habitats (Fogarty \& Botsford 2007, Pelc et al. 2010).

Depending on how connectivity is measured it can have different meanings and implications (e.g. for fisheries management, conservation of species and their evolutionary potential) (Lowe \& Allendorf 2010). Demographic connectivity is the degree to which the subpopulation growth rate is affected by dispersal, and is an important focus for fisheries management. Likewise, genetic connectivity is the degree to which gene flow affects evolutionary processes such as gene frequency and genetic diversity within subpopulations (Lowe \& Allendorf 2010). For both approaches, direct and indirect methods of measurement exist. Direct methods for measuring demographic connectivity, such as capture-markrecapture, are not feasible for marine invertebrate larvae (Lowe \& Allendorf 2010, Pelc et al. 2010). Thus, indirect methods such as coupled biologicaloceanographic models (CBOMs) can inform us about the direction, spatial scale and magnitude of larval dispersion (Werner et al. 2007, Carr et al. 2008, Watson et al. 2010). In contrast, direct methods are available for estimating genetic connectivity, including the use of multiple-locus genotypes to either assign individuals to their subpopulation of origin (Pritchard et al. 2000, Guillot et al. 2005) or conduct parentage analysis (Lowe \& Allendorf 2010). Indirect methods (e.g. $F_{\mathrm{st}}, G_{\mathrm{st}}{ }^{\prime}, D$, private alleles) estimate the degree of genetic differentiation between subpopulations based on the assumption that those subpopulations have reached equilibrium and share the same alleles at the same frequencies. Other indirect methods include the analyses of the spatial scale over which genetic differentiation occurs such as isolation by distance and spatial autocorrelation (Lowe \& Allendorf 2010).

CBOMs simultaneously include key oceanographic and biological factors to provide insights regarding demographic connectivity between specific regions, and allow elaboration of hypotheses about population dynamics. These hypotheses can be further validated, for instance, through field collections of individuals and population genetic analyses (Werner et al. 2007).

Integrating biological variables into physical models can significantly enhance our understanding of biological connectivity (Aiken et al. 2007, Marinone et al. 2008, Siegel et al. 2008). Larval dispersion by marine currents is strongly influenced by the precompetency period (the length of time larvae spend in the plankton), the competency period (when larvae are capable to settle), ontogenic changes in behavior, larval swimming and the timing of spawning (Siegel et al. 2003, Aiken et al. 2007, Watson et al. 2010). Thus, predictive models that integrate biological features, spatial structure of the metapopulation and oceanographic factors are valuable tools for understanding connectivity among fished subpopulations. In fisheries, for instance, if 2 subpopulations show symmetric connectivity, the potential for them to repopulate each other is likely high (Lipcius et al. 2005). However, symmetrical connectivity has been rarely seen in marine species (Gilg \& Hilbish 2003, Cudney-Bueno et al. 2009, Pelc et al. 2009). Conversely, when asymmetrical and directional connectivity is present, identifying source populations and understanding connectivity are crucial steps to avoid over-fishing, particularly in those isolated beds that might be acting as a sole source (Lipcius et al. 2005, Watson et al. 2010).

Although CBOMs have been used to assess connectivity among marine species, validation of model outputs (i.e. coupling theoretical predictions with field data regarding the direction, spatial scale and magnitude of the larval dispersion) has only rarely been performed either directly or indirectly (Pelc et al. 2010, Selkoe et al. 2010), despite the importance of this step for CBOMs to be considered a reliable management tool (Cudney-Bueno et al. 2009, Pelc et al. 2010). Validation has the potential to help determine the model parameter values that are closer to reality. In this regard, determining genetic connectivity of subpopulations through population genetic studies is a powerful tool for corroborating the accuracy of CBOM outputs. Genetic markers such as microsatellites are ideal for this task given their high polymorphism, fast mutation rate and codominance (Beaumont 2006). In addition, sampling larval abundance is often unfeasible in marine bivalves because larvae of many species are difficult to distinguish from each other (Beukers-Stewart et al. 2005, Watson 


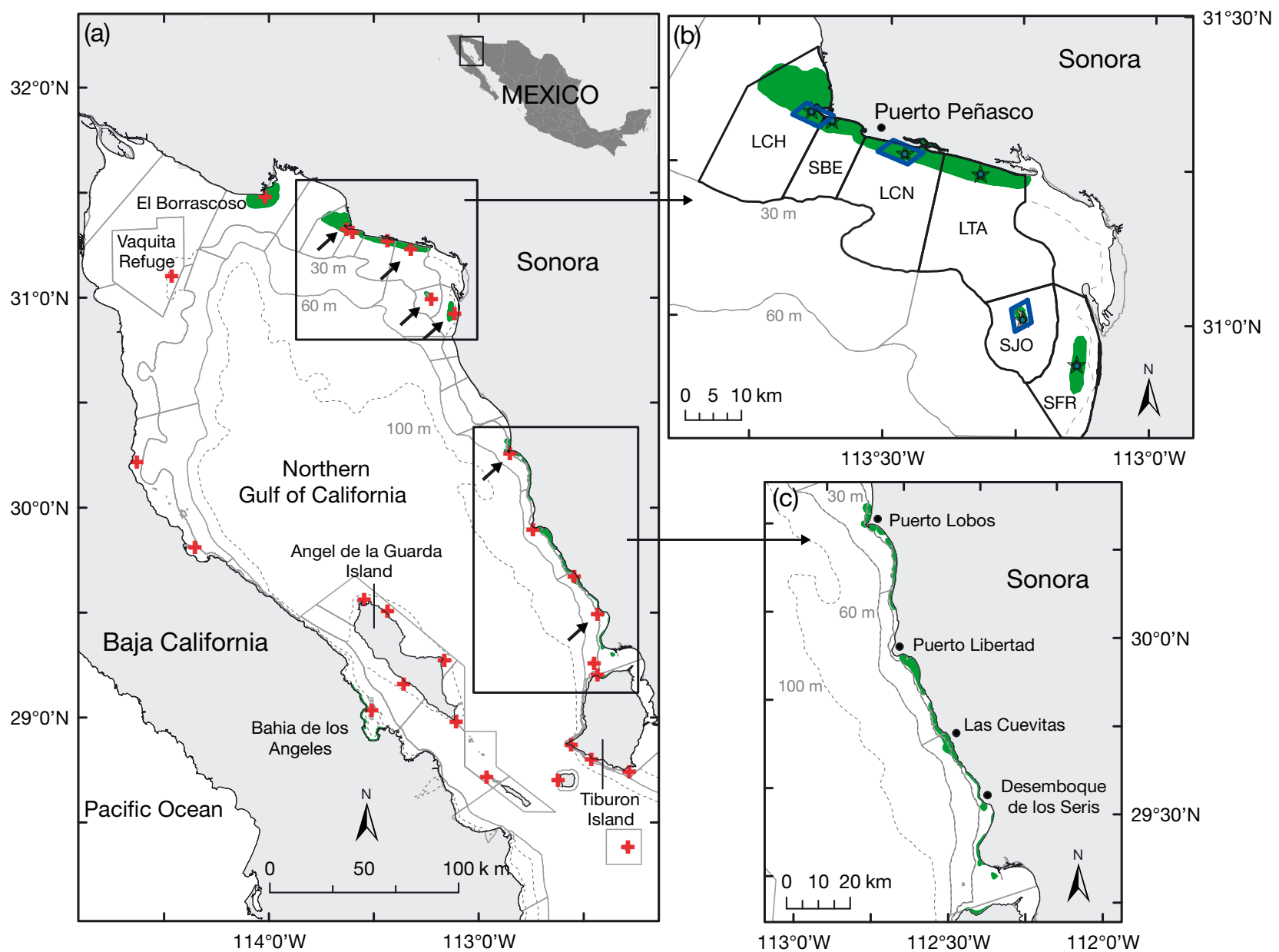

Fig. 1. (a) The northern Gulf of California spatial units of analysis (gray solid lines), particle release sites (red crosses), genetic sample collection sites (arrows), and fishing beds (green zones). (b) Puerto Peñasco corridor and former marine reserves (blue boxes), and selected spatial units of analysis (black solid lines) - LCH: La Cholla; SBE: Sandy Beach; LCN: Las Conchas; LTA: Los Tanques; SJO: San Jorge Island; SFR: San Francisquito. Larva collection sites are depicted with black stars. (c) Southern fishing beds

et al. 2010). However, the recruitment of spat (postsettled larvae) can be used as a proxy of patterns of larval abundance (Arnold et al. 1998, Pelc et al. 2009).

Marine reserves have been advocated as a fishery tool for the management of benthic fisheries in the northern Gulf of California (NGC), Mexico, including the rock scallop Spondylus calcifer (Cudney-Bueno \& Basurto 2009). Locally known as 'escarlopa', the species is fished for its adductor muscle by small-scale, hookah-diving fishers (Cudney-Bueno \& Rowell 2008, Moreno et al. 2008) (Fig. 1). In 2002, a community-based effort led by a fishing cooperative established and enforced an informal marine reserve network (not formally recognized by the government) to protect the declining stocks of Spondylus calcifer and other benthic fisheries within the area they usually fish, the Puerto Peñasco (PP) corridor located in the northeastern portion of the NGC (Fig. 1b) (CudneyBueno et al. 2009).

As part of a separate effort, an oceanographic larval dispersion model was developed to estimate connectivity in the NGC (Marinone et al. 2008). Outputs of this model were considered an 'order zero' view of connectivity as particles were passive, their movement being the result of advection and a random-walk process (to simulate turbulent motion) from a 3-dimensional baroclinic numerical model. This model predicted 2 main dispersal patterns for the summer, when Spondylus calcifer reproduce: (1) the dispersion of particles follows an anticlockwise pattern and (2) particles released from the Baja California Peninsula do not reach the east coast of the NGC, even after 4 mo.

Cudney-Bueno et al. (2009) used this model to evaluate the likely effects of the PP reserves on adjacent areas, comparing model outputs with oceano- 
graphic experiments and observed changes in density of juveniles before and after reserve establishment. Based on this research, Cudney-Bueno et al. (2009) hypothesized that increases of Spondylus calcifer abundances at the northernmost sites of the reserve network could be attributed mainly to sources within the reserve network and that San Jorge Island, in particular, could be acting as a key source for larval export to reserves and fishing grounds on the coast. However, no focused attempts have been made to assess whether larger scale connectivity processes could be playing a role in the observed recruitment benefits after reserve establishment.

The goal of the present study was to examine larval dispersal in the PP region, in particular to assess whether San Jorge Island is the only source that provides larvae to the PP corridor, or if there are other potential sources outside of the reserve network. For this, we developed and enhanced a CBOM for Spondylus calcifer and validated its outputs through 2 techniques: the estimation of population genetic structure with 9 microsatellite loci and the measurement of spat abundance on artificial collectors. Since the horizontal resolution of the former model (Marinone et al. 2008) was somewhat large for detailed local connectivity studies, we used a higher resolution model which incorporates new oceanographic features (Marinone 2008) and improved the model by merging new features into the analysis such as species-specific larval pre-competency period and motility, and new particle release sites based on known fishing sites.

\section{MATERIALS AND METHODS}

\section{Biology of Spondylus calcifer}

Adults of Spondylus calcifer are sessile and inhabit rocky reef areas from the inter-tidal to $55 \mathrm{~m}$ in depth (Poutiers 1995). The species is a gonochoric and broadcast spawner, with an estimated pre-competency period of approximately $2 \mathrm{wk}$ after fertilization under laboratory conditions (Soria et al. 2010). In the NGC, spawning takes place mostly in July, followed by a protracted period of gonad recovery during autumn and winter (Cudney-Bueno \& Rowell 2008). Spawning begins at 86 to $113 \mathrm{~mm}$ in shell height (Villalejo-Fuerte et al. 2002) and 2.5 to 4 yr of age (Cudney-Bueno \& Rowell 2008). Spawn quantity varies between $30 \times 10^{6}$ and $72 \times 10^{6}$ oocytes, and depends on scallop size (Soria et al. 2010). Adults can live at least 10 to 12 yr (Cudney-Bueno \& Rowell 2008) and may grow to $250 \mathrm{~mm}$ in shell height (Skoglund \& Mulliner 1996).

\section{Spatial units of analysis and selection of particle release sites}

To evaluate connectivity, we established spatial units of analysis by combining physical and political information, as well as local knowledge from fishers and our personal observations about Spondylus calcifer fishing beds. The physical domain was defined following the coast line developed by the 'Instituto Nacional de Estadística, Geografía e Informática', Mexico (www.inegi.org.mx); the $30 \mathrm{~m}$ isobath is the limit of the $S$. calcifer fishery and the $60 \mathrm{~m}$ isobath is the depth limit of $S$. calcifer (Poutiers 1995). We incorporated pre-existent political boundaries, such as state and municipal borders, and marine protected areas (CONANP 2009). We relied on fishers' knowledge from 4 fishing communities (Bahía de los Ángeles, Puerto Libertad, Puerto Lobos and Puerto Peñasco) to delimit and select key fishing beds from which to release particles. Local knowledge was obtained by asking fishers to map scallop beds and then digitizing these maps as part of a broader effort to map small-scale fisheries throughout the NGC (Moreno-Báez et al. 2010), because fishers have reliable knowledge of high-density (fishable) beds in most scallop fisheries worldwide (Orensanz et al. 2006). We processed, integrated and analyzed all the digital layers under ArcGIS 9.3 with the Spatial Analyst Extension and Model Builder tools. For the whole NGC we generated 56 spatial units of analysis with estimated areas ranging from 10 to $361 \mathrm{~km}^{2}$, of which 49 were adjacent to the coastline (Fig. 1a).

\section{CBOM development and data analysis}

We used the numerical model of Marinone (2008), which is a 3-dimensional baroclinic numerical Hamburg shelf ocean model (HAMSOM) developed by Backhaus (1985) and adapted to the NGC by Marinone (2003). Briefly, the hydrodynamic model of Marinone (2008) has a high resolution with a mesh size of $\sim 1.31 \times 1.54 \mathrm{~km}$ in the horizontal, and 12 layers in the vertical, with the lower levels fixed at $10,20,30,60,100,150,200,250,350,600,1000$ and $4000 \mathrm{~m}$. Physical forcing includes the open boundary model tide components (M2, S2, N2, K2, K1, O1, P1, Ssa and the Sa), climatological hydrography histori- 
cal data and sea-surface climatological heat and fresh water fluxes. Wind forcing was based on the seasonal climatology constructed from QUICKSCAT data. The model equations are solved semi-implicitly with fully prognostic temperature and salinity fields, thus allowing time-dependent baroclinic motions (Marinone 2008).

The particle trajectories are due to the Eulerian velocity field plus a random-walk contribution related to turbulent eddy diffusion processes following the advection/diffusion scheme described in Visser (1997) and Proehl et al. (2005), i.e. the position of the particles are calculated as follows:

$X(t+\delta t)=X(t)+X_{\mathrm{a}}(t)+R_{\mathrm{x}} \sqrt{ }\left(2 A_{\mathrm{h}} \delta t / 3\right)$

$Y(t+\delta t)=Y(t)+Y_{\mathrm{a}}(t)+R_{\mathrm{y}} \sqrt{ }\left(2 A_{\mathrm{h}} \delta t / 3\right)$

$Z(t+\delta t)=Z(t)+Z_{\mathrm{a}}(t)+R_{\mathrm{z}} \sqrt{ }\left(2 A_{\mathrm{v}} \delta t / 3\right)+\delta t \delta A_{\mathrm{v}} / \delta Z$

where $(X, Y, Z)$ are the particle positions in the zonal, meridional and vertical directions, respectively, at time $t . X_{\mathrm{a}}, Y_{\mathrm{a}}$ and $Z_{\mathrm{a}}$ are the advective displacements obtained by integrating the velocity field, $\underline{V}_{\underline{a}}(x, y, z)=$ $[u(x, y, z), v(x, y, z), w(x, y, z)]$. The velocity at each particle position is calculated by bilinear interpolation of the instantaneous Eulerian velocity fields from the numerical model, which were saved every hour. $R_{\mathrm{x}}$, $R_{\mathrm{Y}}$ and $R_{\mathrm{z}}$ are random variables between -1 and 1 (Visser 1997). $A_{\mathrm{h}}$ is the horizontal eddy diffusivity and is constant $\left(A_{\mathrm{h}}=100 \mathrm{~m}^{2} \mathrm{~s}^{-1}\right)$, as in the Eulerian numerical model. In the particle tracking algorithm, the results are similar with different values of the horizontal diffusion coefficient, indicating that the dominant process is advection. $A_{\mathrm{v}}$ is the vertical diffusivity, which is also taken from the Eulerian numerical model, and is calculated and interpolated for the individual particle positions at each time step. In the Eulerian numerical model $A_{\mathrm{v}}$ is calculated following Kochergin (1987).

We released 400 particles (i.e. virtual larvae) from 28 sites (total 11200) matching known locations of fishing beds based on fishers' knowledge and from sites within established marine protected areas in the NGC (Fig. 1a). We chose to use 400 particles since previous runs of the model with larger numbers (up to 4000) of particles did not improve relative percentages of particles reaching sink destinations at any given time. From the output of the model, we calculated particles' trajectories following the advection/ diffusion scheme described in Marinone et al. (2008). We conducted simulations for the 4 combinations of 2 release dates (spring tide, 15 July 2007, or neap tide, 22 July 2007) and 2 larval behaviors (active or passive motility of the particles). We differentiated the motility capacity of the larvae in 3 stages: (1) embryonic phase in which larvae stay at the bottom for $1 \mathrm{~d}$ while they develop from fertilized egg to straighthinge larva, (2) veliger phase when larvae are completely passive and reach the competency period after $14 \mathrm{~d}$ and (3) pediveliger phase in which larvae have a tendency to move toward the bottom. These behaviors were simulated in the model, which has advection in all directions ( $x, y$ and $z$ ), as follows: in the first stage we set the vertical velocity to 0 so the particles were only advected horizontally; in the third stage the particles were freely advected when the vertical velocity was towards the bottom, but was set to zero when the velocity was positive (towards the surface) such that only horizontal advection was allowed.

We tracked particle positions (latitude and longitude) every hour after the release time and queried the data by means of ArcGIS 9.3 to obtain the abundance and origin of the particles reaching every spatial unit of analysis within the PP corridor. For each simulation, we obtained the position of each particle for 2 scenarios: low and high tides. Then, from the different CBOM outputs we selected the 2 cases as proxies for (1) the lower dispersion case (position at low tide of active particles released at neap tide) and (2) the higher dispersion case (position at high tide of passive particles released at spring tide), based on overall average dispersion distances. We selected a $2 \mathrm{wk}$ period as the settlement time period (Soria et al. 2010) and compared the results with 1 and 3 wk settlement periods.

In addition, for each of the 6 spatial units of analysis within the PP corridor (Fig. 1b), we calculated the density of particles in each spatial unit $\left(W_{i}\right)$ relative to the total number of particles arriving in the corridor and to the area of the spatial unit of analysis.

We employed a spatial directed network (Treml et al. 2007) constructed with the software NODEXL (M. Smith et al., http://nodexl.codeplex.com/) to visualize the observed probabilities of dispersal from each source to each potential site (i.e. the proportion of larvae that settled at each location relative to the total number of virtual larvae released at each source, averaged over the 2 release dates).

\section{Population genetic structure: microsatellite markers analysis}

We collected and preserved in $70 \%$ ethanol $\sim 1 \mathrm{~g}$ of adductor muscle from Spondylus calcifer individuals from 6 localities (populations) where particles were 
released, including 4 localities within the PP corridor (La Cholla, Los Tanques, San Jorge Island, San Francisquito) and 2 sites located southwards (Puerto Lobos and Desemboque de los Seris) (Fig. 1a). We extracted genomic DNA using the DNeasy blood and tissue kit (Qiagen). Following Munguía-Vega et al. (2010), we amplified all samples by the polymerase chain reaction (PCR) and genotyped every individual at 10 polymorphic nuclear microsatellite DNA loci (Spca4, Spca9, Spca16, Spca34, Spca61, Spca1A, Spca9B, Spca12, Spca24 and Spca39). We performed genotyping on an ABI PRISM 3730XL Genetic Analyzer (Applied Biosystems), estimated allele sizes using GENOTYPER 3.7 and classified them into bins with FLEXIBIN (Amos et al. 2007).

We estimated deviations from Hardy-Weinberg equilibrium per locus and population, and linkage equilibrium between pairs of loci with FSTAT 2.9.3.2 (Goudet 1995). We obtained adjusted p-values using a sequential Bonferroni test for multiple comparisons (Rice 1989) with $\alpha=0.05$. We calculated the number of alleles $\left(\mathrm{N}_{\mathrm{A}}\right)$, the effective number of alleles $\left(\mathrm{N}_{\mathrm{E}}\right)$, which corrects for differences in sample size among samples, and observed $\left(H_{\mathrm{O}}\right)$ and expected $\left(H_{\mathrm{E}}\right)$ heterozygosities, in GENALEX (Peakall \& Smouse 2006). Then, we calculated levels of genetic differentiation (i.e. differences in allele frequencies) between pairs of sampled localities with the fixation index $\left(F_{\mathrm{st}}\right)$ and the standardized measure $G_{\text {st }}{ }^{\prime}$ (Hedrick 2005), which measures true differentiation for highly polymorphic loci such as microsatellites (Jost 2008). We calculated mean $F_{\mathrm{st}}$ and $G_{\mathrm{st}}$ values and $95 \%$ confidence intervals (CI) using the software of Neff \& Fraser (2010), resampling individuals and loci 1000 times.

We estimated the spatial scale of genetic structure with a spatial autocorrelation analysis implemented in GENALEX. This method uses both pairwise geographical and squared genetic distance matrices from individual samples to generate a spatial autocorrelation coefficient (r) among individuals within 5 even-distance bins (50 $\mathrm{km}$ each). We selected the number and size of bins to ensure that at least 30 data points occurred in each bin (Rossi et al. 1992). The coefficient provides a measure of the genetic similarity between pairs of individuals within each bin, allowing the identification of critical distances beyond which dispersal effects are weak (i.e. genetic neighborhood size) (Wright 1978). Statistical significance was achieved by 1000 permutations and 1000 bootstrap replicates to estimate $95 \%$ CI.

To estimate the number of genetic clusters $(K)$ present throughout the geographical range of the sampled localities, we employed the Bayesian clus- tering method implemented in GENELAND (Guillot et al. 2008). We generated 10 independent runs of $1 \times$ $10^{6}$ Markov chain Monte Carlo (MCMC) iterations, sampling every 1000th, with a number of predefined genetic clusters $(K)$ ranging from 1 to 6 (i.e. the number of localities sampled). This was performed by means of the spatial model with null alleles, with a maximum of 300 nuclei, without uncertainty on coordinates, and correlated allele frequencies to improve the detection of subtle genetic structure (Guillot 2008). We discarded the first $25 \%$ of the run as the burn-in period, and sampled the posterior distribution of $K$ values to estimate $K$ mode.

For comparison with the GENELAND model, we used the software STRUCTURE 2.3.1 (Hubisz et al. 2009). This model allows for structure to be detected at the low levels of divergence that characterize many marine populations (Palumbi 2003) without biasing towards detecting structure when it is not present (Hubisz et al. 2009). We performed 10 independent STRUCTURE runs for a number of $K$ ranging from 1 to 6 . In each run, we included a burn-in period of $1 \times 10^{5} \mathrm{MCMC}$ repetitions followed by $1 \times$ $10^{5}$ repetitions to sample from the posterior distribution. We assumed admixture and correlated allele frequencies as recommended for cases of low differentiation (Falush et al. 2003). To estimate the most likely number of $K$, we used the $\Delta K$ method (Evanno et al. 2005) as implemented in STRUCTURE HARVESTER (http://taylor0.biology.ucla.edu/struct_harvest). We considered individuals with an assignment probability $<50 \%$ to the population where they were sampled as misassigned and with a predominantly migrant ancestry.

\section{Temporal and spatial variation of spat abundance}

In 2007 and 2008, we estimated recruitment of Spondylus calcifer spat in the PP corridor on artificial collectors deployed on each spatial unit covering $\sim 75 \mathrm{~km}$ of coastline (Fig. 1b). These sites corresponded with the location of particle release sites. At each site, we deployed 3 lines moored by one end to an anchor and by the other end to a plastic buoy (buoyancy $=5 \mathrm{~kg}$ ). We enclosed polyethylene collectors (Netlon: $200 \times 40 \mathrm{~cm}$; mesh opening $=7 \times 12 \mathrm{~mm}$ ) into a plastic bag $(60 \times 40 \mathrm{~cm}$; mesh opening $=0.8 \times$ $1 \mathrm{~mm}$ ) and tied each bag to the main rope at 1, 3, 5 and $7 \mathrm{~m}$ from the bottom.

We deployed collectors on 22 June 2007 and 27 June 2008, and retrieved them after 2 mo by SCUBA diving. We detached the spat by washing the collec- 
tors and sieving each sample through a $250 \mu$ m nylon mesh, and transferred it to a plastic pan to be counted under a dissecting scope. We used a repeated-measures analysis of variance (longitudinal study) to test significant differences in the number of recruited spat between years, sites and depth. We applied a natural logarithmic transformation $[\ln (x+1)]$ to the numbers of spat per collector to meet assumptions of normality and homogeneity of variances. For 2007, we obtained the proportion of settled spat $\left(O_{i}\right)$ on each collection site relative to the total number of spat settled within the PP corridor and correlated this estimate with the values of relative abundance of particles $\left(W_{i}\right)$.

\section{RESULTS}

\section{CBOM output for the PP corridor}

Overall, the cloud of particles showed cyclonic dispersion (Fig. 2). At 2 wk, for the lower dispersion case (position at low tide of active particles released at neap tide), there was a significant influence of particles from southern remote release sites such as Puerto Lobos (15 to $93 \%$ of the particles arriving to each spatial unit) and Puerto Libertad ( $<5$ to $72 \%$ ), located $\sim 100$ and $\sim 150 \mathrm{~km}$ south of the corridor, respectively (Fig. 2). For the higher dispersion case (position at high tide of passive particles released at spring tide), we observed an even higher incidence (about $5 \%$ more) of particles arriving to the corridor from these distant sources. The output for the higher dispersion case resulted in the occurrence of particles from more remote areas, as particles traveled longer distances from southern sources (Table 1, Fig. 2).

The estimated mean linear distance of dispersal at 2 wk ranged between 50 and $135 \mathrm{~km}$, depending on the site of origin (Table 1). Two sites located at the northwest limit of the PP corridor (La Cholla and Sandy Beach) had a lower mean larval dispersal ( 66 to $72 \mathrm{~km}$ ) than the central sites $(77$ to $93 \mathrm{~km}$, Las Conchas, Los Tanques). Of the 6 sites within the PP corridor, San Jorge Island had the lowest mean larval dispersal distance ( 47 to $56 \mathrm{~km}$ ) at all times. Puerto Lobos and Puerto Libertad had the highest mean linear distance (109 to $135 \mathrm{~km}$ ) (Table 1).

At $2 \mathrm{wk}$, San Jorge and Puerto Lobos were the main sources of particles reaching La Cholla for both dispersal cases (Fig. 3b). For Sandy Beach, Las Conchas and Los Tanques, the remote site of Puerto Lobos was the main source of particles (68 to $93 \%$ ), with minor inputs from San Jorge Island (4 to $22 \%$, except for los Tanques), San Francisquito (10 to 18\%) and Puerto Libertad (1 to $25 \%$ ). Particles released from Puerto Libertad contributed to San Jorge Island (up to $85 \%$ ) and San Francisquito (72\%) (Figs. 2 \& $3 b)$. San Francisquito was the only spatial unit receiving particles from Las Cuevitas, and only for the higher dispersion case.
Fig. 2. Final positions of particles from the coupled biological-oceanographic model for Spondylus calcifer: output at 2 wk for (a) higher dispersion case (spring tide, 15 July 2007) and (b) lower dispersion case (neap tide, 22 July 2007). Color at each release site (crosses) matches its particle's colors. VAQ: Vaquita Refuge; EBO: El Borrascoso; LCH: La Cholla; SBE: Sandy Beach; LCN: Las Conchas; LTA: Los Tanques; SJO: San Jorge Island; SFR: San Francisquito; PLO: Puerto Lobos; PLI: Puerto Libertad; LCU: Las Cuevitas; DDS: Desemboque de los Seris; ITIn: Tiburón Island (north); AGI: Angel de la Guarda Island
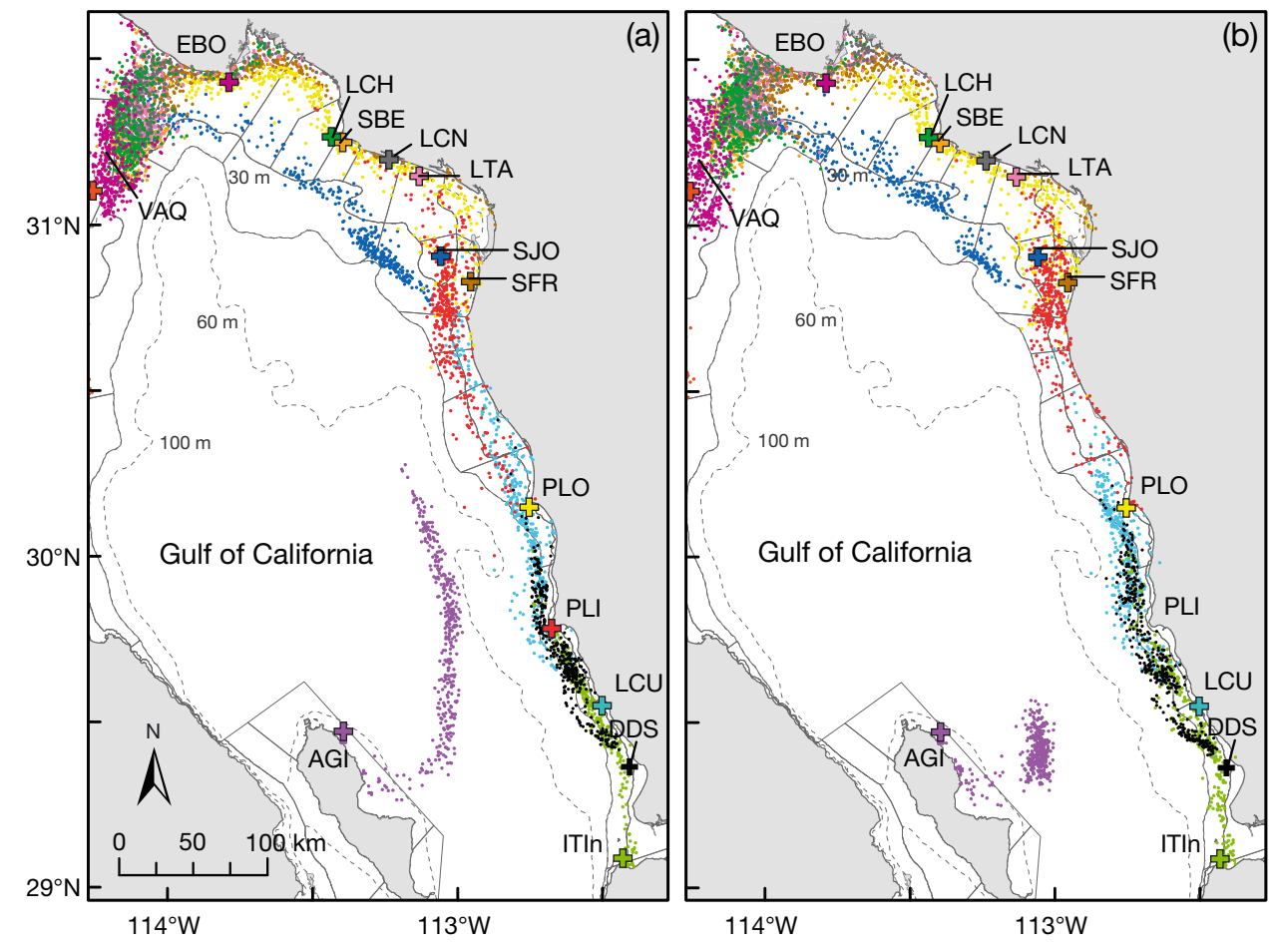
Table 1. Linear distance $(\mathrm{km})$ traveled by particles released at different sites. Higher dispersion case (HD) and lower dispersion case (LD). Mean $\pm \mathrm{SD}$ values

\begin{tabular}{|c|c|c|c|c|c|c|}
\hline \multirow[t]{2}{*}{ Site } & \multicolumn{2}{|c|}{$1 \mathrm{wk}$} & \multicolumn{2}{|c|}{$2 \mathrm{wk}$} & \multicolumn{2}{|c|}{$3 \mathrm{wk}$} \\
\hline & HD & LD & HD & LD & HD & LD \\
\hline La Cholla & $56.6 \pm 8.3$ & $53.9 \pm 10.7$ & $67.8 \pm 8.4$ & $66.4 \pm 7.4$ & $78.9 \pm 10.1$ & $77.0 \pm 8.9$ \\
\hline Sandy Beach & $58.0 \pm 9.5$ & $62.1 \pm 4.9$ & $72.3 \pm 4.9$ & $68.0 \pm 8.6$ & $83.7 \pm 6.6$ & $77.9 \pm 9.5$ \\
\hline Las Conchas & $60.9 \pm 12.3$ & $58.2 \pm 13.6$ & $80.2 \pm 13.5$ & $77.3 \pm 12.1$ & $89.4 \pm 13.8$ & $86.4 \pm 11.6$ \\
\hline Los Tanques & $70.2 \pm 10.6$ & $67.9 \pm 11.4$ & $93.4 \pm 10.1$ & $90.0 \pm 10.3$ & $101.6 \pm 10.0$ & $97.9 \pm 9.6$ \\
\hline San Jorge Island & $44.7 \pm 27.7$ & $30.3 \pm 25.5$ & $47.8 \pm 34.7$ & $56.0 \pm 29.5$ & $54.1 \pm 32.6$ & $60.1 \pm 28.5$ \\
\hline San Francisquito & $60.5 \pm 19.8$ & $53.4 \pm 15.4$ & $104.8 \pm 22.8$ & $101.0 \pm 26.3$ & $118.0 \pm 18.7$ & $113.2 \pm 23.2$ \\
\hline Puerto Lobos & $74.3 \pm 13.3$ & $77.0 \pm 14.2$ & $135.2 \pm 34.6$ & $117.5 \pm 28.9$ & $165.6 \pm 31.3$ & $157.2 \pm 34.8$ \\
\hline Puerto Libertad & $65.7 \pm 21.5$ & $55.7 \pm 20.7$ & $109.5 \pm 25.8$ & $110.9 \pm 22.7$ & $140.4 \pm 37.5$ & $141.5 \pm 38.4$ \\
\hline Las Cuevitas & $21.3 \pm 8.6$ & $30.6 \pm 13.2$ & $71.6 \pm 30.8$ & $56.0 \pm 20.3$ & $116.5 \pm 37.1$ & $84.1 \pm 33.1$ \\
\hline Desemboque de los Seris & $22.6 \pm 9.6$ & $22.2 \pm 9.5$ & $44.9 \pm 20.0$ & $44.5 \pm 23.2$ & $76.9 \pm 35.7$ & $62.9 \pm 35.9$ \\
\hline
\end{tabular}

Assuming that larvae are capable of reaching the competency period in $1 \mathrm{wk}$, our model suggests that San Francisquito and San Jorge Island were the main sources of particles seeding La Cholla, Sandy Beach and Las Conchas (70 to $80 \%$ San Francisquito and 35 to $50 \%$ San Jorge Island; Fig. 3a). Particles released from San Francisquito were advected towards the coast, while those released from San Jorge Island went offshore (Fig. 2). For Los Tanques, San Francisquito was the main source, accounting for $\sim 75 \%$ of the particles. More than $90 \%$ of the particles arriving at San Jorge Island and San Francisquito originated in Puerto Lobos (Table 1, Fig. 3a).

If we assume that larvae can delay settlement until the third week, San Jorge Island, Puerto Lobos and Puerto Libertad would be contributing equally to northwestern areas of the PP corridor. The southeastern limit of the corridor received particles mainly from Puerto Libertad and Las Cuevitas (Figs. 2 \& 3c). The central area (Las Conchas and Los Tanques) was a transition zone, primarily receiving particles from southern areas (Fig. 3c). During the 1 to $3 \mathrm{wk}$ modeled, particles from the southernmost site (Desemboque de los Seris) never reached the PP corridor.

With the exception of San Jorge Island and San Francisquito, particles released from sites within the PP corridor were exported to downstream sites, outside the former reserve network, and towards northwest regions such as El Borrascoso and the Vaquita Refuge (Figs. 1 to 4). At $2 \mathrm{wk}$, El Borrascoso was mainly seeded by particles released from sites within the PP corridor and from Puerto Lobos (5 to 26\%), whereas El Borrascoso was the primary source of particles for the Vaquita Refuge (Figs. 2 \& 4).

In terms of the potential sources for Puerto Lobos and Puerto Libertad, at 1 wk Puerto Libertad was the main source for Puerto Lobos with a much lower contribution from Las Cuevitas $(<5 \%)$, while particles released from southern reefs such as Las Cuevitas and Desemboque de los Seris were the main sources (70 and $30 \%$, respectively) for Puerto Libertad, with minor contributions from the northern region of Tiburon Island. At 2 and $3 \mathrm{wk}$, particles from Las Cuevitas (80 and 50\%, respectively) and other southern sites including Desemboque de los Seris (10 to $45 \%$, respectively), reached Puerto Lobos (Figs. 2 \& 5).

\section{Population genetic structure: microsatellite analysis}

We genotyped 176 individuals from 6 localities at each of 10 microsatellite loci. Locus Spca24 was excluded from the analysis because it was duplicated in some of the sampled localities, precluding accurate assignment of alleles to a particular locus. From the remaining 9 loci, there was no evidence of significant deviations from Hardy-Weinberg equilibrium in 54 tests for each locus in each population (all p > 0.0009). From a total of 204 tests of departures from linkage equilibrium covering all pairs of loci and localities, there were no instances of significant disequilibrium ( $p>0.0002)$. Therefore, we assumed loci to be independent in all subsequent analyses.

There was moderate genetic variation among sampled localities. The mean $\mathrm{N}_{\mathrm{A}}$ varied from 8.3 to 9.7 , while the mean $\mathrm{N}_{\mathrm{E}}$ ranged from 4.2 to 4.8. Mean $H_{\mathrm{O}}$ and $H_{\mathrm{E}}$ ranged from 0.504 to 0.593 and 0.579 to 0.668 , respectively (Table 2). Over all populations, there was very low population genetic structure $\left(F_{\mathrm{st}}=\right.$ $0.008 ; 95 \% \mathrm{CI}=-0.001$ to 0.021$). F_{\text {st }}$ and $G_{\text {st }}{ }^{\prime}$ estimates were approximately proportional. Between pairs of localities, San Francisquito-Los Tanques 
(a) One week
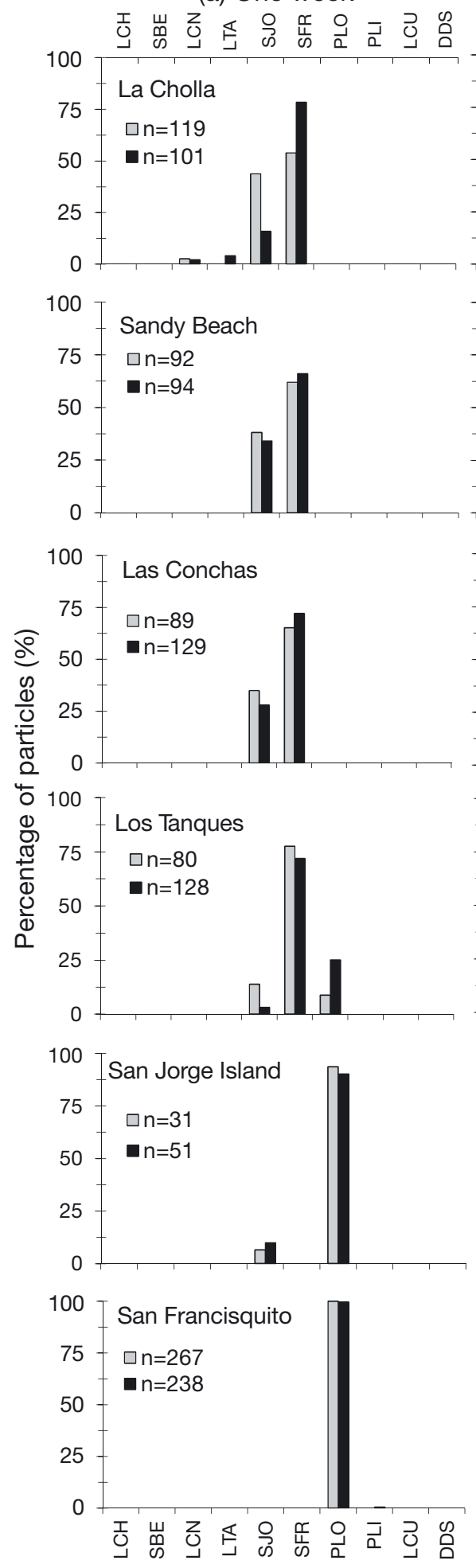

(b) Two weeks
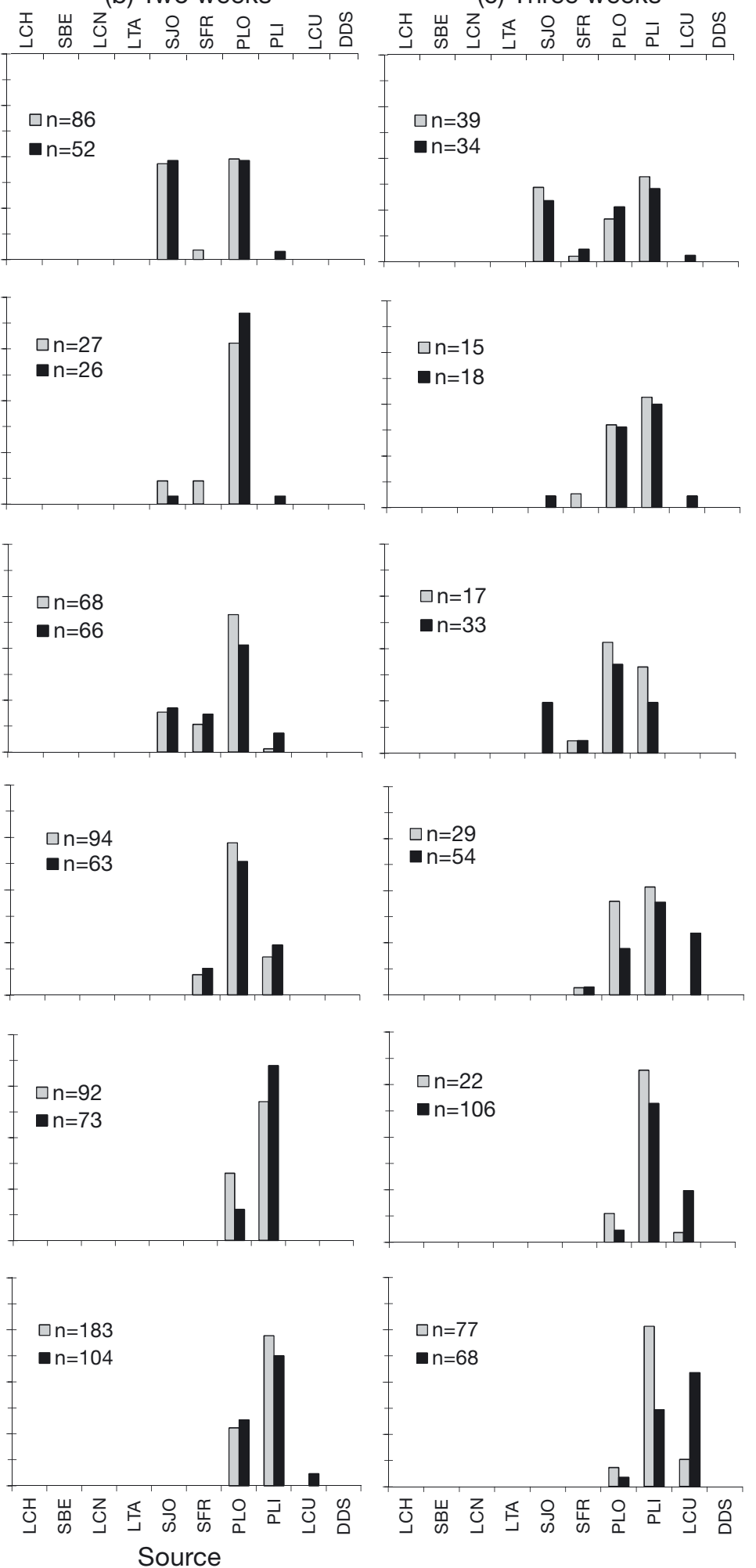

(c) Three weeks

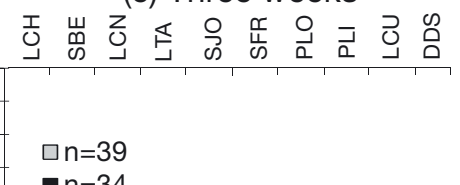

an=34
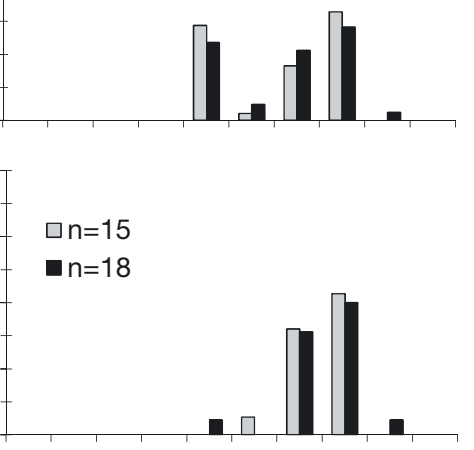

$\square \mathrm{n}=17$

an=33
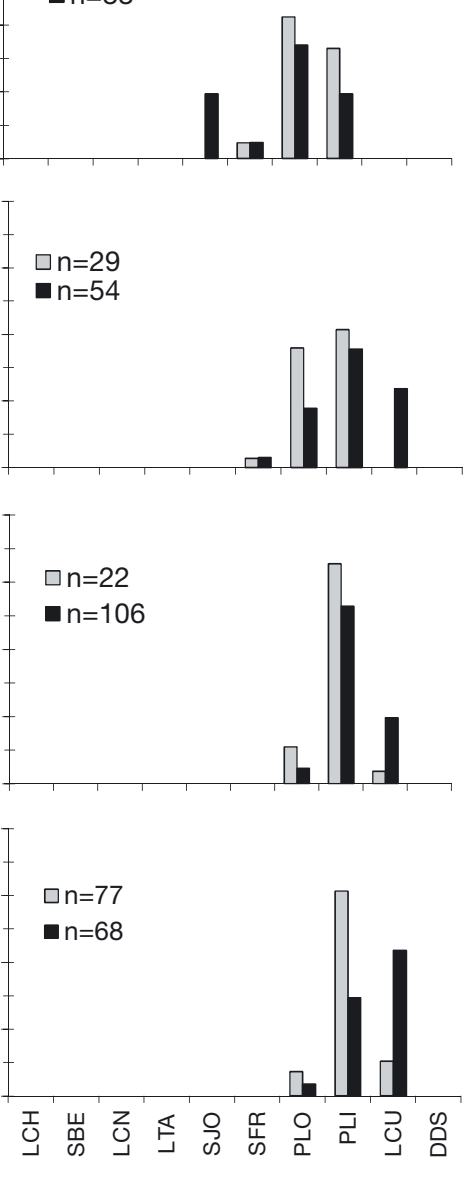

Fig. 3. Percentage distribution of modeled particles arriving at the Puerto Peñasco corridor sites from the release sites (source) at (a) 1, (b) 2 and (c) 3 wk. Gray bars: lower dispersion case (position at low tide of active particles released at neap tide); black bars: higher dispersion case (position at high tide of passive particles released at spring tide); LCH: La Cholla; SBE: Sandy Beach; LCN: Las Conchas; LTA: Los Tanques; SJO: San Jorge Island; SFR: San Francisquito; PLO: Puerto Lobos; PLI: Puerto Libertad; LCU: Las Cuevitas; DDS: Desemboque de los Seris 


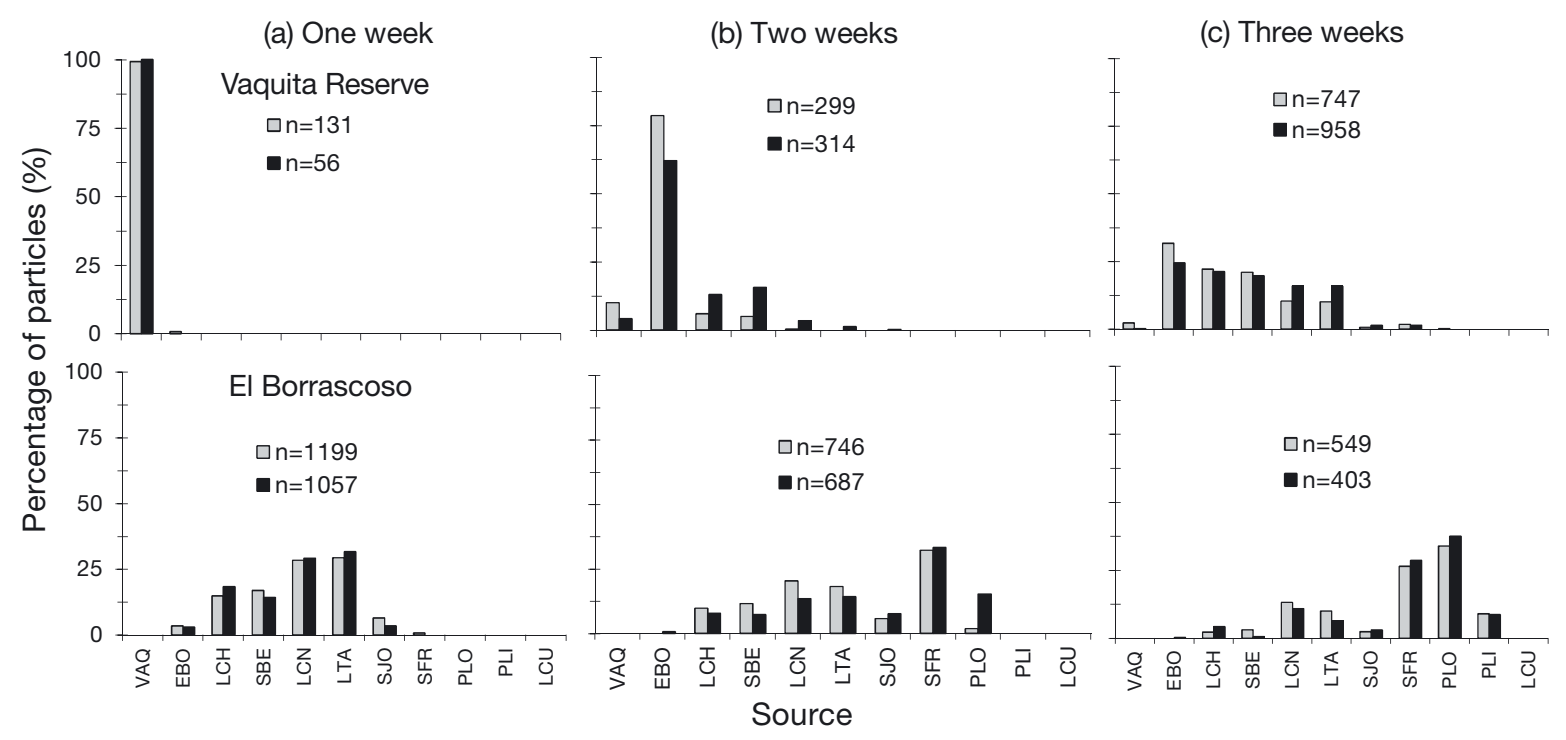

Fig. 4. Percentage distribution of modeled particles arriving at Vaquita Refuge and El Borrascoso (downstream of the Puerto Peñasco corridor) at (a) 1, (b) 2 and (c) 3 wk. Gray bars: lower dispersion case (position at low tide of active particles released at neap tide); black bars: higher dispersion case (position at high tide of passive particles released at spring tide); VAQ: Vaquita Refuge; EBO: EL Borrascoso; LCH: La Cholla; SBE: Sandy Beach; LCN: Las Conchas; LTA: Los Tanques; SJO: San Jorge Island; SFR: San Francisquito; PLO: Puerto Lobos; PLI: Puerto Libertad; LCU: Las Cuevitas

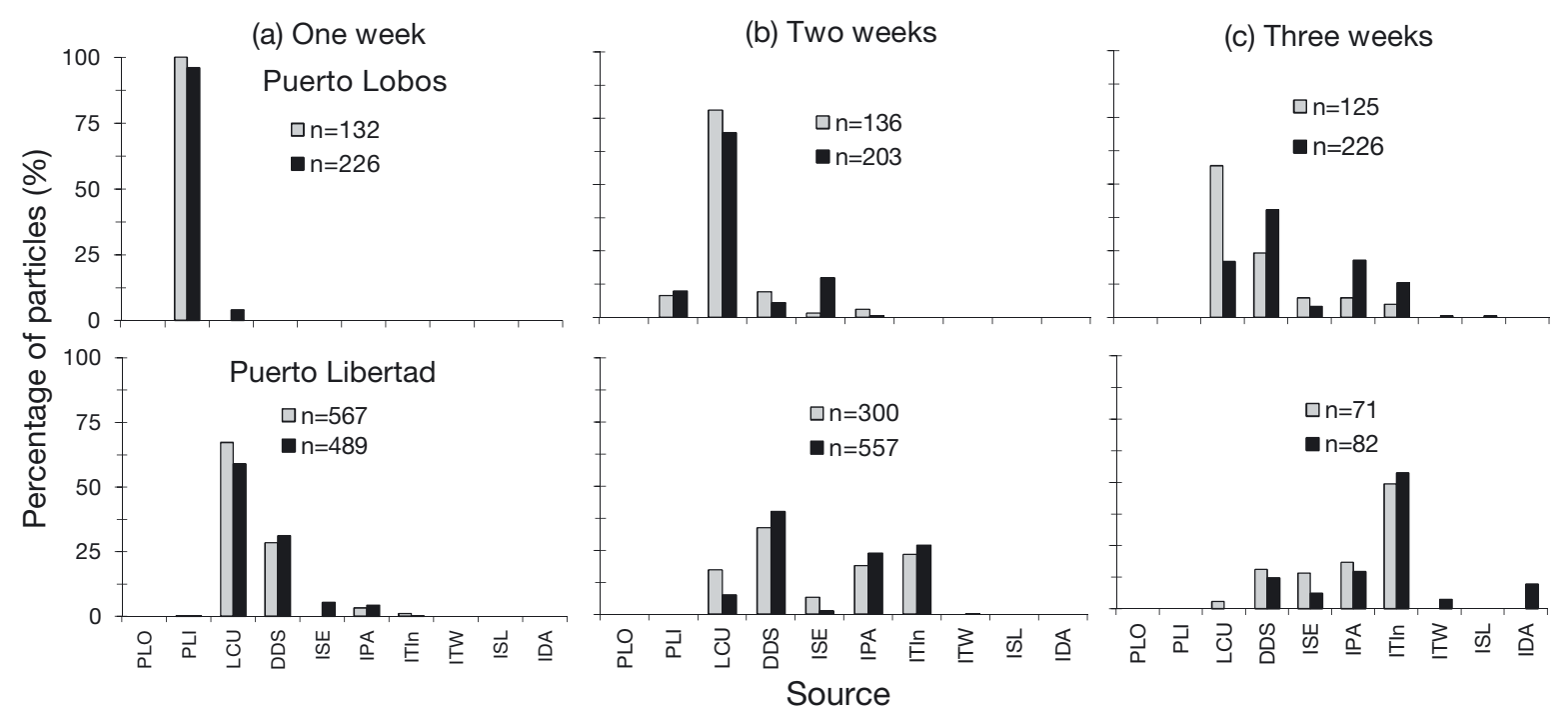

Fig. 5. Percentage distribution of modeled particles arriving at Puerto Lobos and Puerto Libertad (upstream of the Puerto Peñasco corridor) at (a) 1, (b) 2 and (c) 3 wk. Gray bars: lower dispersion case (position at low tide of active particles released at neap tide); black bars: higher dispersion case (position at high tide of passive particles released at spring tide); PLO: Puerto Lobos; PLI: Puerto Libertad; LCU: Las Cuevitas; DDS: Desemboque de los Seris; ISE: San Esteban Island; IPA: Patos Island; ITIn: Tiburón Island (north); ITW: Tiburón Island (west); ISL: San Lorenzo Island; IDA: El Dátil Island

showed the lowest mean population genetic structure $\left(F_{\mathrm{st}}=0.020 ; 95 \% \mathrm{CI}=-0.017,0.080\right.$; and $G_{\mathrm{st}}{ }^{\prime}=$ $0.039 ; 95 \% \mathrm{CI}=-0.025,0.138)$, whereas San Francisquito-San Jorge Island had the highest differentiation $\left(F_{\mathrm{st}}=0.044 ; 95 \% \mathrm{CI}=-0.003,0.129 ;\right.$ and $G_{\mathrm{st}}{ }^{\prime}=$ $0.086 ; 95 \% \mathrm{CI}=-0.004,0.228$ ) (Table 3 ).

Based on the analysis of spatial autocorrelation $(\mathrm{r})$, only individuals within the first distance bin
(0 to $50 \mathrm{~km}$ ) showed significant positive correlation, suggesting that Spondylus calcifer individuals were genetically more similar than expected by random distribution $(\mathrm{r}=0.008, \mathrm{p}=0.01)$ (Fig. 6). There was no significant genetic spatial structure for bins 50-100, 100-150 and 150-200 km. The last bin $(200-250 \mathrm{~km})$ showed significant negative correlation $(\mathrm{r}=-0.008, \mathrm{p}=0.02)$. The distance at which 
Table 2. Genetic variation among localities. Sample size $(\mathrm{N})$, mean \pm SE numbers of alleles $\left(\mathrm{N}_{\mathrm{A}}\right)$, effective alleles $\left(\mathrm{N}_{\mathrm{E}}\right)$, and observed $\left(H_{\mathrm{O}}\right)$ and expected $\left(H_{\mathrm{E}}\right)$ heterozygosities

\begin{tabular}{|lccccc|}
\hline Population & $\mathrm{N}$ & $\mathrm{N}_{\mathrm{A}}$ & $\mathrm{N}_{\mathrm{E}}$ & $H_{\mathrm{O}}$ & $H_{\mathrm{E}}$ \\
\hline La Cholla & 32 & $9.444 \pm 1.788$ & $4.202 \pm 1.145$ & $0.504 \pm 0.095$ & $0.583 \pm 0.100$ \\
Los Tanques & 32 & $9.778 \pm 1.839$ & $4.857 \pm 1.263$ & $0.51 \pm 0.0961$ & $0.630 \pm 0.097$ \\
San Jorge Island & 18 & $8.333 \pm 1.555$ & $4.737 \pm 1.386$ & $0.545 \pm 0.093$ & $0.629 \pm 0.096$ \\
San Francisquito & 32 & $9.111 \pm 1.874$ & $4.710 \pm 1.199$ & $0.514 \pm 0.101$ & $0.579 \pm 0.118$ \\
Puerto Lobos & 30 & $9.556 \pm 1.804$ & $4.363 \pm 1.089$ & $0.568 \pm 0.100$ & $0.611 \pm 0.098$ \\
Desemboque de los Seris & 32 & $9.667 \pm 1.650$ & $4.897 \pm 1.043$ & $0.593 \pm 0.092$ & $0.668 \pm 0.093$ \\
\hline
\end{tabular}

Table 3. Genetic differentiation between pairs of localities. Mean (95\% CI, in parentheses) $F_{\text {st }}$ (above diagonal) and $G_{\text {st }}{ }^{\prime}($ below diagonal) values

\begin{tabular}{|c|c|c|c|c|c|c|}
\hline & $\begin{array}{c}\text { La } \\
\text { Cholla }\end{array}$ & $\begin{array}{c}\text { Los } \\
\text { Tanques }\end{array}$ & $\begin{array}{l}\text { San Jorge } \\
\text { Island }\end{array}$ & $\begin{array}{c}\text { San } \\
\text { Francisquito }\end{array}$ & $\begin{array}{l}\text { Puerto } \\
\text { Lobos }\end{array}$ & $\begin{array}{c}\text { Desemboque } \\
\text { de los Seris }\end{array}$ \\
\hline $\begin{array}{l}\text { La } \\
\text { Cholla }\end{array}$ & & $\begin{array}{c}0.031 \\
(-0.006,0.088)\end{array}$ & $\begin{array}{c}0.027 \\
(-0.006,0.083)\end{array}$ & $\begin{array}{c}0.024 \\
(-0.012,0.082)\end{array}$ & $\begin{array}{c}0.033 \\
(-0.001,0.087)\end{array}$ & $\begin{array}{c}0.032 \\
(-0.002,0.079)\end{array}$ \\
\hline $\begin{array}{l}\text { Los } \\
\text { Tanques }\end{array}$ & $\begin{array}{c}0.06 \\
(-0.014,0.168)\end{array}$ & & $\begin{array}{c}0.037 \\
(-0.003,0.110)\end{array}$ & $\begin{array}{c}0.02 \\
(-0.017,0.080)\end{array}$ & $\begin{array}{c}0.038 \\
(-0.002,0.104)\end{array}$ & $\begin{array}{c}0.03 \\
(-0.003,0.085)\end{array}$ \\
\hline $\begin{array}{l}\text { San Jorge } \\
\text { Island }\end{array}$ & $\begin{array}{c}0.06 \\
(-0.013,0.173)\end{array}$ & $\begin{array}{c}0.072 \\
(-0.007,0.199)\end{array}$ & & $\begin{array}{c}0.044 \\
(-0.003,0.129)\end{array}$ & $\begin{array}{c}0.026 \\
(-0.003,0.076)\end{array}$ & $\begin{array}{c}0.031 \\
(-0.002,0.089)\end{array}$ \\
\hline $\begin{array}{l}\text { San } \\
\text { Francisquito }\end{array}$ & $\begin{array}{c}0.048 \\
(-0.026,0.176)\end{array}$ & $\begin{array}{c}0.039 \\
(-0.025,0.138)\end{array}$ & $\begin{array}{c}0.086 \\
(-0.004,0.228)\end{array}$ & & $\begin{array}{c}0.04 \\
(-0.006,0.114)\end{array}$ & $\begin{array}{c}0.031 \\
(-0.004,0.087)\end{array}$ \\
\hline $\begin{array}{l}\text { Puerto } \\
\text { Lobos }\end{array}$ & $\begin{array}{c}0.074 \\
(0.000,0.175)\end{array}$ & $\begin{array}{c}0.081 \\
(0.000,0.207)\end{array}$ & $\begin{array}{c}0.061 \\
(-0.008,0.171)\end{array}$ & $\begin{array}{c}0.082 \\
(-0.005,0.230)\end{array}$ & & $\begin{array}{c}0.029 \\
(-0.004,0.084)\end{array}$ \\
\hline $\begin{array}{l}\text { Desemboque } \\
\text { de los Seris }\end{array}$ & $\begin{array}{c}0.07 \\
(-0.004,0.186)\end{array}$ & $\begin{array}{c}0.063 \\
(-0.006,0.166)\end{array}$ & $\begin{array}{c}0.069 \\
(-0.009,0.183)\end{array}$ & $\begin{array}{c}0.064 \\
(-0.006,0.171)\end{array}$ & $\begin{array}{c}0.069 \\
(-0.005,0.202)\end{array}$ & \\
\hline
\end{tabular}

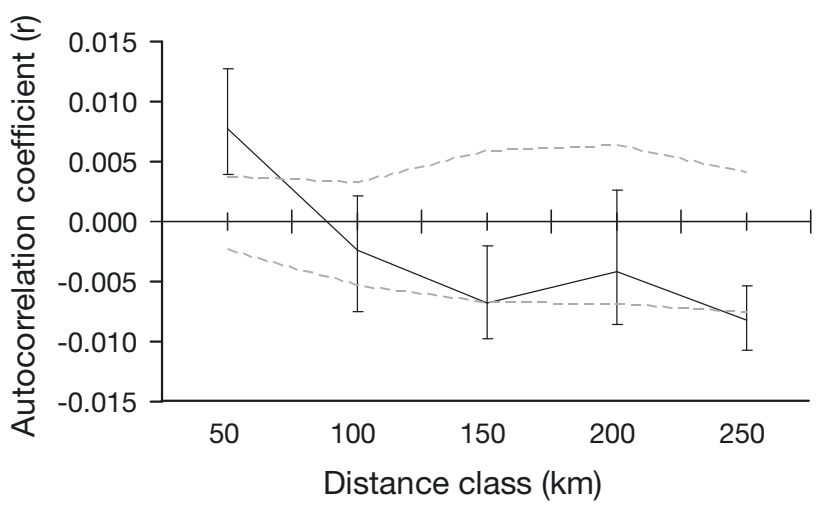

Fig. 6. Spatial autocorrelation coefficient (r) among individuals of Spondylus calcifer. The genetic similarity between pairs of individuals within each distance class is measured by $r$. Positive values indicate individuals are genetically more similar than expected by random. Bars represent $95 \%$ CI. Dashed lines represent upper and lower confidence limits bound the $95 \%$ CI about the null hypothesis of no spatial structure for the combined data set as determined by permutation. When $r=0$, distance class length $=88.1 \mathrm{~km}$ the positive autocorrelation broke down was estimated at $88.1 \mathrm{~km}$ (i.e. $\mathrm{r}=0$ ).

We consistently estimated a mode of 2 genetic clusters after performing 10 independent GENELAND runs (Fig. 7a). One genetic cluster was composed of La Cholla, Los Tanques and San Francisquito, while the second cluster included San Jorge Island and the 2 southern localities of Puerto Lobos and Desemboque de los Seris (Fig. 7b). However, there were very low levels of genetic differentiation $\left(F_{\mathrm{st}}=0.007\right)$ between these 2 clusters. On the other hand, the standard STRUCTURE model (Pritchard et al. 2000, Falush et al. 2003) was unable to detect population structure between the samples because of the low levels of differentiation (pairwise $F_{\text {st }} \leq 0.044$; Table 3) (Latch et al. 2006, Hubisz et al. 2009). Using information about sampling location to modify the probability that any 2 individuals are assigned to the same cluster (Hubisz et al. 2009), we estimated the highest mean value of the ln probability of data (and lowest variation around the estimate) for $K=1$ (average $\ln [K]=-4966.21 ;$ Fig. 8a), suggesting an absence of 


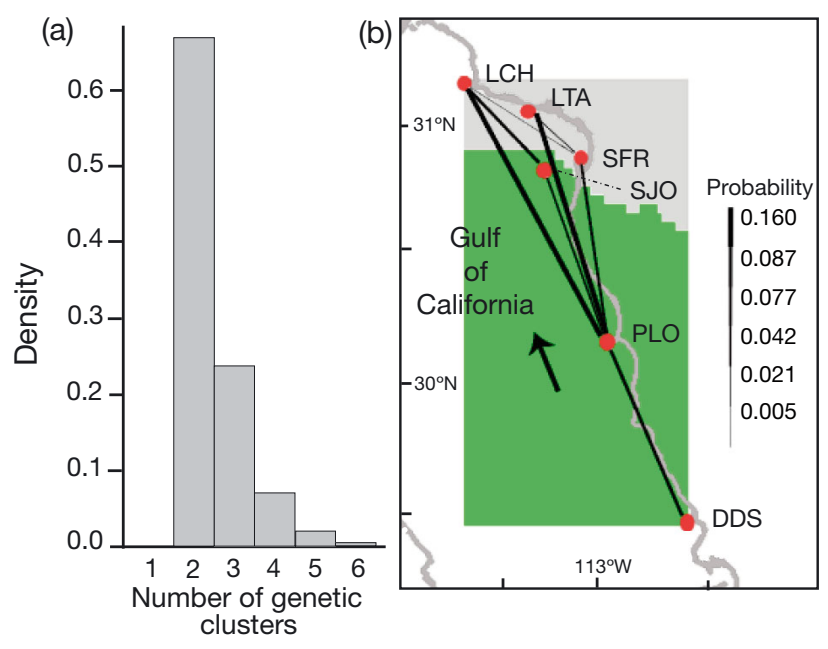

Fig. 7. GENELAND's clustering algorithm: (a) posterior distribution of the number of distinct genetic clusters and (b) sampling localities (red dots) and the assignments to the 2 genetic clusters (green and gray, respectively), and the probabilities of larval dispersal estimated from the model at 2 wk between localities (nodes) are displayed in a directed spatial network. The arrow shows the direction of the unidirectional oceanic flow. LCH: La Cholla; LTA: Los Tanques; SFR: San Francisquito; SJO: San Jorge Island; PLO: Puerto Lobos; DDS: Desemboque de los Seris

population structure throughout the sampled localities. The $\Delta K$ method suggested that $K=3$ (average $\ln [K]=-5001.88$ ) was the most likely value. However, this method cannot find the best $K$ if the true $K=1$ (Evanno et al. 2005), as suggested by the ln probability of the data. For comparison with the GENELAND output, the mean individual assignment probabilities are shown when $K=2$ (average $\ln [K]=$ -4992.23; Fig. 8b). Here, the percentage of individuals assigned to a southern genetic cluster declined (shown in red) from Desemboque de los Seris $(93.7 \%)$ and Puerto Lobos $(96.7 \%)$, to San Jorge Island $(72.2 \%)$, San Francisquito $(65.6 \%)$, Los Tanques $(87.5 \%)$ and La Cholla (81.2\%).

The comparison of genetic data at 2 wk with the spatial network (Fig. 7b) indicated the presence of 8 links among the 6 localities. From these, half of the links suggested by the spatial network were consistent with the spatial clustering based on multilocus genotypes (i.e. 4 links found between localities assigned to the same genetic cluster). However, the spatial network model was inconsistent with the genetic data in 2 aspects: the suggestion that larvae from Puerto Lobos readily reach the coastal sites in the Puerto Peñasco corridor and the fact that larvae from San Jorge Island are dispersed to the last downstream site in the corridor (La Cholla).
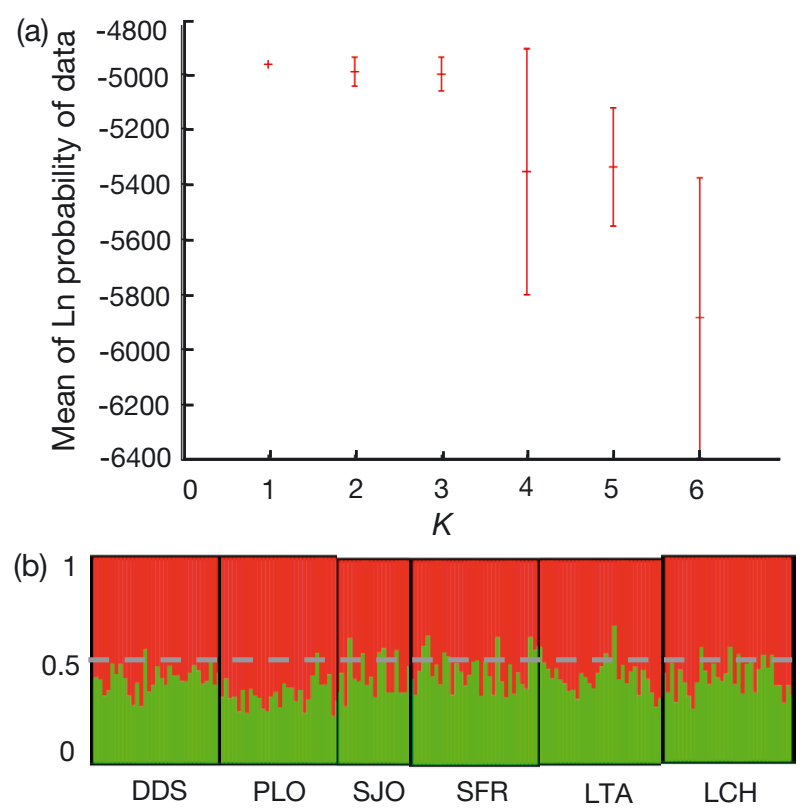

Fig. 8. STRUCTURE's clustering algorithm: (a) mean and standard deviation of ln probability of data for no. of genetic clusters $(K)=1$ to 6 and (b) bar plot showing the mean individual assignment probabilities among 10 independent replicates of $K=2$ (red: southern cluster; green: northern cluster). DDS: Desemboque de los Seris; PLO: Puerto Lobos; SJO: San Jorge Island; SFR: San Francisquito; LTA: Los Tanques; LCH: La Cholla

\section{Temporal and spatial variation of spat abundance}

Overall, recruitment of Spondylus calcifer spat did not differ between spawning seasons (repeated-measures 3-way ANOVA; $F_{1,65}=2.22, \mathrm{p}=0.14$ ), but it was significantly influenced by location (repeated-measures 3 -way ANOVA; $F_{1,5}=7.42, \mathrm{p}<0.001$ ) (Fig. 9). At each depth (considering all localities) there were no significant differences between years (repeatedmeasures 3 -way ANOVA; $F_{1,65}=0.32, \mathrm{p}<0.86$ ). In $2007,70 \%$ of all recruited spat for the corridor corresponded to spat recruited at San Jorge Island and San Francisquito (both sites pooled). However, in 2008 , this value was reduced to $55 \%$ for these localities taken together, and spat recruitment at La Cholla represented $25 \%$ (Fig. 9).

For summer 2007 at Week 1, both lower and higher dispersion cases had no correlation between the relative abundances of recruited spat $\left(O_{i}\right)$ and predicted particles $\left(W_{i}\right)$ (higher dispersion case: $\mathrm{r}=0.360, \mathrm{p}=$ 0.484 ; lower dispersion case: $\mathrm{r}=0.361, \mathrm{p}=0.482$ ). At Week $2, O_{i}$ and $W_{i}$ had significant correlation (higher dispersion case: $\mathrm{r}=0.920, \mathrm{p}=0.009$; lower dispersion case: $\mathrm{r}=0.894, \mathrm{p}=0.016)$. At Week $3, O_{i}$ and $W_{i}$ correlated positively, but only for the higher dispersion case $(\mathrm{r}=0.886, \mathrm{p}=0.019)$ (Fig. 10). 


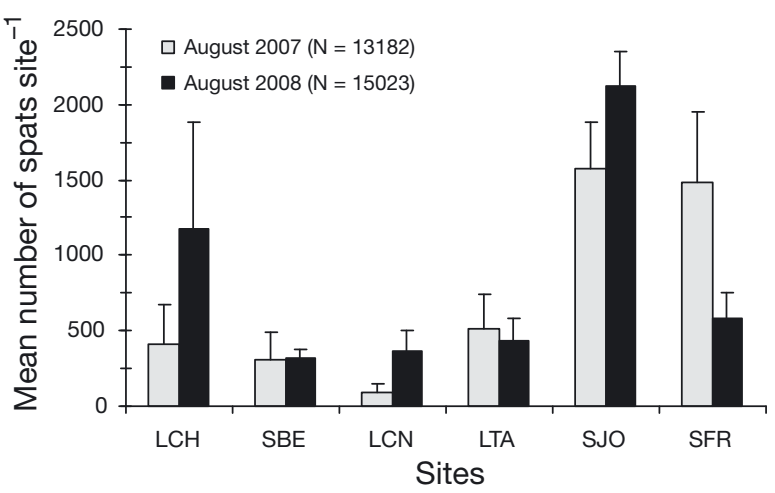

Fig. 9. Mean number $( \pm \mathrm{SD})$ of Spondylus calcifer spat recruited on artificial collectors pooled per site and year. LCH: La Cholla; SBE: Sandy Beach; LCN: Las Conchas; LTA: Los Tanques; SJO: San Jorge Island; SFR: San Francisquito

\section{DISCUSSION}

Predicted values from CBOM's outputs suggest connectivity between the PP corridor and southern sources such as Puerto Lobos (located $150 \mathrm{~km}$ south), which was supported by genetic data. CBOM's outputs also suggested that sources located further south, such as Puerto Libertad, Las Cuevitas $(\sim 175 \mathrm{~km}$ away) and Desemboque de los Seris ( $200 \mathrm{~km}$ away) likely have weak connectivity links with the corridor. Furthermore, modeling larvae as active particles reduced connectivity, a pattern consistent with slower transport in sub-surface waters (Shanks et al. 2003), since effects from remote areas were even more restricted.

Apparent contradictions between CBOM and genetic outputs could be due to the limitation of the model to represent dispersal over multiple generations and extreme stochastic events (e.g. hurricanes, El Niño-Southern Oscillation) that could disperse potential larvae from remote sources under such extreme conditions. Other important issues might be related to the low number of simulated spawning events (multi-year events), the limited number of particles released for each site (400) and inaccuracies in the actual spawning locations. Attention to this complexity requires further studies because a weak representation of long-distance dispersers could lead to underestimation of the frequency of long-distance dispersers that drive the $F_{\mathrm{st}}$ and $G_{\mathrm{st}}$ values. For example, although the contribution of Desemboque de los Seris to the corridor could be of small demographic importance, as suggested by the CBOM, it is plausible that a few larvae from that locality could reach

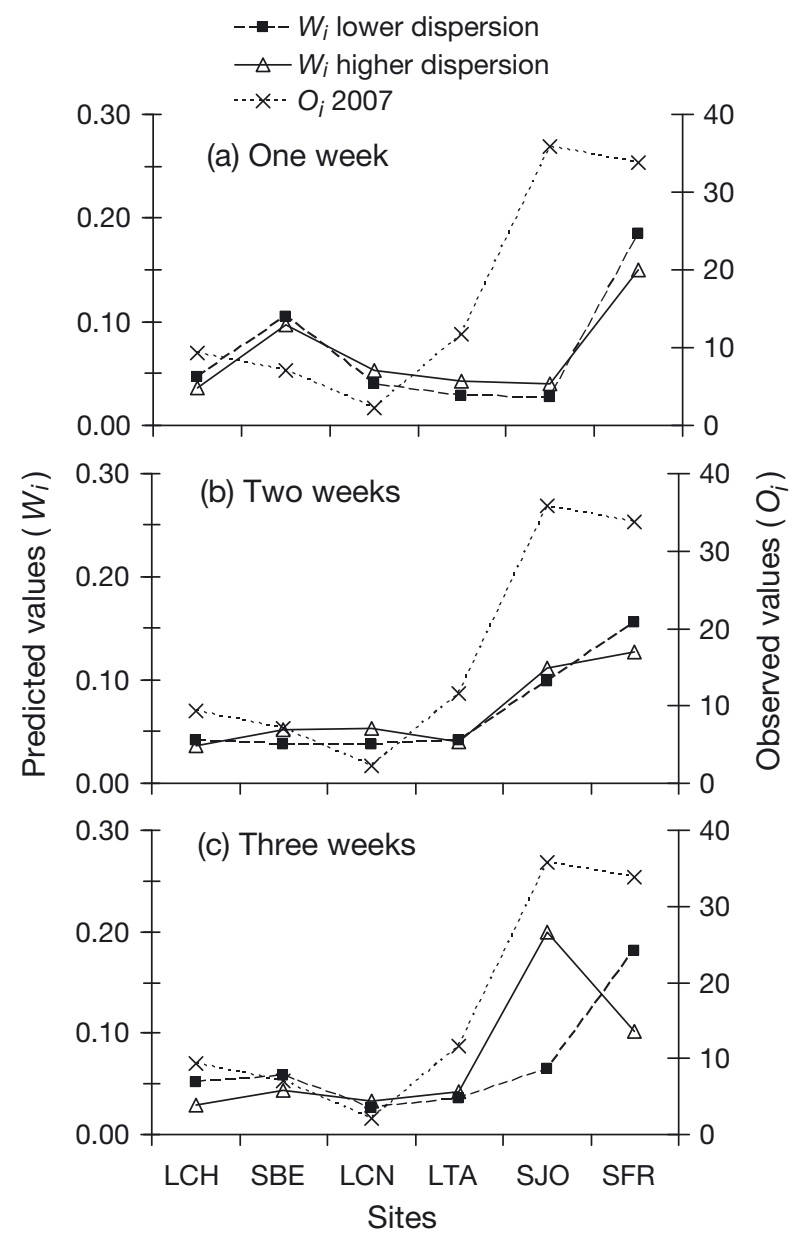

Fig. 10. Correlation between relative abundances of predicted values $\left(W_{i}\right)$ and observed relative values of Spondylus calcifer spat recruited on artificial collectors $\left(O_{i}\right)$ at (a) 1 , (b) 2 and (c) 3 wk for the lower dispersion case (position at low tide of active particles released at neap tide) and higher dispersion case (position at high tide of passive particles released at spring tide). LCH: La Cholla; SBE: Sandy Beach; LCN: Las Conchas; LTA: Los Tanques; SJO: San Jorge Island; SFR: San Francisquito

the corridor over multiple generations as suggested by genetic analysis.

In the present study, measures of genetic differentiation suggested low genetic structure in pairwise comparisons of sampled localities $\left(F_{\mathrm{st}}<0.05\right.$ and $G_{\mathrm{st}}{ }^{\prime}$ $<0.09$; Table 3). The low genetic differentiation suggests that at least a few larvae disperse, settle and reproduce across the study area. In theory, 1 effective migrant per generation between distant localities is enough to ensure that alleles are shared among populations over evolutionary time (Wright 1978), which would preserve the adaptive potential of the populations and avoid the harmful effects of genetic drift and inbreeding. Our results imply the presence of adaptive and inbreeding genetic connec- 
tivity (see Lowe \& Allendorf 2010) between the PP corridor and the reefs located $\sim 200 \mathrm{~km}$ south, but not under moderate levels of gene flow or random mating (Palumbi 2003, Hedgecock et al. 2007). Compared to other systems (White et al. 2010), the unidirectional flow in the NGC greatly simplifies the identification of source populations, for instance, within a $100 \mathrm{~km}$ window capturing demographic connectivity for summer spawners. In such an asymmetric system, upstream populations are predicted to drive patterns of genetic structure throughout the entire area (Pringle et al. 2011) and are thus critical for population viability and evolutionary adaptation.

Our estimates of genetic connectivity suggest overall uninterrupted gene flow among sampled localities. However, we characterized 2 subtly differentiated spatial components and an incipient genetic cline; a southern cluster, including San Jorge Island, Puerto Lobos and Desemboque de los Seris, and a northern cluster, including San Francisquito, Los Tanques and La Cholla. Migration rates $>1$ migrant per generation, and consequently Hardy-Weinberg equilibrium, are needed within each cluster (but not between them) to maintain nearly identical allele frequencies (Lowe \& Allendorf 2010). It is noteworthy that Spondylus calcifer individuals from San Francisquito and San Jorge Island, located close to each other $(<10 \mathrm{~km})$, had the highest levels of genetic structure (Table 3). Hence, larval exchange between these sites appears to be restricted. Larvae produced at San Francisquito might be dispersed following a nearshore pathway, whereas larvae from the island might follow offshore dispersal. Likewise, in spite of San Jorge Island appearing as a minor source for the northwest sites of the corridor (La Cholla, Sandy Beach and Las Conchas) in the CBOM and spatial network model, which contradicts the spatial location of the northern genetic cluster identified, the CBOM also suggested a lack of dispersal between the island and Los Tanques, located $25 \mathrm{~km}$ to the north. This latter observation is consistent with the location of the boundary between the 2 genetic clusters. These observations suggest that the dynamics of larval dispersal in nearshore coastal waters over a small geographic scale can be complex and that differences in along-shore flow velocity and direction, for instance, associated with a coastal boundary layer, can produce local dynamics with major consequences on population structure (Largier 2003). Similarly, weak genetic structure in 3 coastal marine species along the west coast of California and Baja California was ecologically meaningful when correlated with environmental (e.g. temperature) and ecological (e.g. kelp distribution) variables, instead of oceanographic pathways (Selkoe et al. 2010).

The estimated low levels of genetic structure among sampled localities, without implementation of a CBOM, would have precluded identification of the probable importance of upstream sources for the corridor and their dispersal pathways. Subtle gene structure occurs in marine invertebrates (Palumbi 2003, Kenchington et al. 2006, Selkoe et al. 2010), and most genetic studies provide little or inconclusive information on demographic connectivity (Lowe \& Allendorf 2010). In these situations CBOMs complement population genetic studies and help to define connectivity among sites under different spatial and temporal scales. We posit that single-year estimates of connectivity and genetic structure accumulated over 30 to 50 generations operate at a similar spatial scale and tend to decrease when the spatial scale exceeds $100 \mathrm{~km}$, in agreement with studies suggesting that dispersal distances estimated from genetic data are similar to those observed for short planktonic larval durations, but, at longer durations, genetic data generally overestimate dispersal distances (Gilg \& Hilbish 2003, Shanks 2009). Our findings are also consistent with larval dispersal distances (range 30 to $100 \mathrm{~km}$ ) estimated for mussels through elemental fingerprints (Becker et al. 2007) and rate of range expansion (McQuaid \& Phillips 2000). Also, mean larval dispersal distances for various fish and invertebrates with pelagic larvae have been estimated at 25 to $150 \mathrm{~km}$ (Palumbi 2003, Sotka \& Palumbi 2006).

For the corridor, higher values of both predicted particles and observed densities of Spondylus calcifer juveniles (<100 $\mathrm{mm}$ in shell height) were reported for the northern sites of La Cholla and Sandy Beach, and lower abundances, for the central areas (Las Conchas and Los Tanques) (CudneyBueno et al. 2009). Our results underscore this gradient and also suggest that San Jorge Island and San Francisquito will have higher spat recruitment than other sites. In both years, San Jorge Island had the highest spat recruitment, accounting for 35 and $45 \%$ of the total recruited spat in the corridor. This higher recruitment might explain the higher densities of S. calcifer individuals (both juveniles and adults) around the island (up to 1.6 scallops $\mathrm{m}^{-2}$ ), in compar-

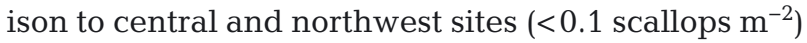
(Cudney-Bueno et al. 2009). We observed high consistency between predicted abundances of particles and observed spat ( $<5 \mathrm{~mm}$ in shell height) on artificial collectors, in particular for Weeks 2 and 3; however, more research is needed to supply greater con- 
fidence on the causative factors explaining these correlations. Nonetheless, we successfully applied a methodology to collect spat which could be used to perform further studies to test the origin of the spat (Becker et al. 2007, Werner et al. 2007), or to implement stock enhancement programs through massive collection and seeding of spat.

Our results also suggest that Spondylus calcifer beds within the corridor share multiple sources of larvae south of San Jorge Island, such that larval recruitment within the corridor is not entirely due to local production and is linked to a broader suite of larval sources, including southern sources $(\sim 100 \mathrm{~km}$ south of the corridor). For San Jorge Island, CudneyBueno et al. (2009) suggested compensatory effects as a plausible explanation of the lack of increase in density of juveniles of $S$. calcifer, even after years of protection. Our results suggest that the lack of enhanced densities could also be attributed to larger spatial scale processes involving stock-recruitment relationships, driven by larval production outside the corridor.

Within the corridor, San Jorge Island, Sandy Beach and Las Conchas were formerly proposed as marine reserves (Cudney-Bueno et al. 2009). However, it is likely that the island is acting as a key component for larval export towards sites in the northwestern limit of the corridor, rather than towards south-central sites. As for Sandy Beach and Las Conchas, their main contribution is also predicted to be towards northwestern sites, but given the short geographic proximity $(<10 \mathrm{~km})$ between them, these sites could be considered as a single unit as suggested by the estimated spatial scale of connectivity.

Our findings provide information about the direction and geographical scale of larval dispersion. Slight differences in allele frequencies among sampled localities suggest the absence of a strong barrier to migration. Consequently, the siting of marine reserves at upstream sites would likely benefit downstream subpopulations, given the coastal circulation along the eastern side of the NGC throughout summer, when the species reproduce. Moreover, the spatial scale of demographic and genetic connectivity, as estimated through the CBOM and genetic analysis $(\sim 100 \mathrm{~km})$, might be used as a geographical reference for siting marine reserves. Closing or reducing the fishing area will initially reduce the availability of harvestable scallops, which, by shifting harvesting pressure elsewhere, could lead to unpredictable consequences on other stocks (Hilborn et al. 2004). If San Jorge Island, Puerto Lobos, San Francisquito, or any other combination of sites is to be selected as a mar- ine reserve, the demographic contribution of each site, the likely movement of fishing pressure and the compliance of the fishing sector must be addressed.

The accuracy of the CBOM's outputs could be further improved by performing more formal contrasts of genetic and oceanographic distance matrices, incorporating dispersal over multiple generations (White et al. 2010), and by addressing other processes that drive population connectivity (Cowen \& Sponaugle 2009). The inclusion of differences in reproductive timing among localities, improvements on the representation of spawning areas and the number of particles simulated, available settlement habitat, estimation of population densities and larval attenuation due to natural mortality would allow the model to simulate variation in larval delivery from genetically different subpopulations. Furthermore, larval swimming capabilities, ontogenic depth preferences, differential growth rates and differential fishing pressure were not addressed in the present study, but could be integrated into the modeling as information on these topics is made available.

The value of combining genetic and demographic methods for understanding spatial and temporal scales of connectivity has been highlighted recently (Lowe \& Allendorf 2010, Selkoe et al. 2010). In particular, the CBOM and spatial network model allowed us to identify the most likely sources of larvae contributing to local recruitment, which influences population growth in fishing beds of the PP corridor. Nonetheless, our model predictions likely underestimate the magnitude of long-term patterns of connectivity, as captured by our genetic methods, because larval dispersal can vary interannually and over decades. These features have recently been incorporated into the CBOM framework (Selkoe et al. 2010, White et al. 2010). Moreover, the use of genetic methods made it possible to verify a continuous unidirectional flow that has likely homogenized population structure over 100 to $200 \mathrm{~km}$, highlighting the value of connectivity models and genetic studies in marine reserve design.

Acknowledgements. We thank A. Cinti, W. Shaw, T. Pfister, M. Lavin and P. Turk-Boyer and 2 anonymous reviewers and Dr. R. Lipcius for revising and providing helpful comments. We are grateful to W. Ludt, D. Manjon, J. Hall and R. LoaizaVillanueva and the Buzos de Puerto Punta Peñasco fishing cooperative for their field and laboratory support. We collected scallop spat under Permit No. SGPA/DGVS 01349/08 issued to CEDO by the SEMARNAT agency in Mexico. This work was funded by The David and Lucile Packard Foundation, The Nature Conservancy and the Conservancy's R. J. Kose Grant Program. This is a scientific contribution to the PANGAS Project (www.pangas.arizona.edu). 


\section{LITERATURE CITED}

Aburto-Oropeza O, Erisman B, Galland GR, MascareñasOsorio I, Sala E, Ezcurra E (2011) Large recovery of fish biomass in a no-take marine reserve. PLoS ONE 6: e23601

Aiken CM, Navarrete SA, Castillo MI, Castilla JC (2007) Along-shore larval dispersal kernels in a numerical ocean model of the central Chilean coast. Mar Ecol Prog Ser 339:13-24

Amos W, Hoffman JI, Frodsham A, Zhang L, Best S, Hill AVS (2007) Automated binning of microsatellite alleles: problems and solutions. Mol Ecol Notes 7:10-14

> Arnold WS, Marelli DC, Bray CP, Harrison MM (1998) Recruitment of bay scallops Argopecten irradians in Floridan Gulf of Mexico waters: scales of coherence. Mar Ecol Prog Ser 170:143-157

$>$ Backhaus JO (1985) A three-dimensional model for the simulation of the shelf sea dynamics. Dtsch Hydrogr Z 38: 165-187

Beaumont A (2006) Genetics. In: Shumway SE, Parsons GJ (eds) Scallops: biology, ecology and aquaculture, Vol 35. Elsevier, Amsterdam, p 543-594

Becker BJ, Levin LA, Fodrie FJ, McMillan PA (2007) Complex larval connectivity patterns among marine invertebrate populations. Proc Natl Acad Sci USA 104: 3267-3272

> Beukers-Stewart BD, Vause BJ, Mosley MWJ, Rossetti HL, Brand AR (2005) Benefits of closed area protection for a population of scallops. Mar Ecol Prog Ser 298:189-204

Carr S, Capet X, McWilliams J, Pennington T, Chavez F (2008) The influence of diel vertical migration on zooplankton transport and recruitment in an upwelling region: estimates from a coupled behavioral-physical model. Fish Oceanogr 17:1-15

CONANP (Comisión Nacional de Areas Naturales Protegidas) (2009) Mapa de Áreas Naturales Protegidas. CONANP, Mexico City. Available at: http://sig.conanp. gob.mx/website/anpsig/viewer.htm (accessed 20 January 2012)

- Cowen RK, Sponaugle S (2009) Larval dispersal and marine population connectivity. Annu Rev Mar Sci 1:443-466

Crowder LB, Lyman SJ, Figueira WF, Priddy J (2000) Source-sink population dynamics and the problem of siting marine reserves. Bull Mar Sci 66:799-820

Cudney-Bueno R, Basurto X (2009) Lack of cross-scale linkages reduces robustness of community-based fisheries management. PLoS ONE 4:e6253

Cudney-Bueno R, Rowell K (2008) Establishing a baseline for management of the rock scallop Spondylus calcifer (Carpenter, 1857): growth and reproduction in the Upper Gulf of California, Mexico. J Shellfish Res 27:625-632

> Cudney-Bueno R, Lavín MF, Marinone SG, Raimondi PT, Shaw WW (2009) Rapid effects of marine reserves via larval dispersal. PLoS ONE 4:e4140

Evanno G, Regnaut S, Goudet J (2005) Detecting the number of clusters of individuals using the software structure: a simulation study. Mol Ecol 14:2611-2620

Falush D, Stephens M, Pritchard JK (2003) Inference of population structure using multilocus genotype data: linked loci and correlated allele frequencies. Genetics 164: 1567-1587

Fogarty MJ, Botsford LW (2007) Population connectivity and spatial management of marine fisheries. Oceanography (Wash DC) 20(3):112-123
Gell FR, Roberts CM (2003) Benefits beyond boundaries: the fishery effects of marine reserves. Trends Ecol Evol 18: 448-455

Gilg MR, Hilbish TJ (2003) The geography of marine dispersal: coupling genetics with fine-scale physical oceanography. Ecology 84:2989-2998

Goudet J (1995) FSTAT (Version 1.2): a computer program to calculate F-statistics. J Hered 86:485-486

Guillot G (2008) Inference of structure in subdivided populations at low levels of genetic differentiation-the correlated allele frequencies model revisited. Bioinformatics 24:2222-2228

Guillot G, Estoup A, Mortier F, Cosson JF (2005) A spatial statistical model for landscape genetics. Genetics 170: 1261-1280

Guillot G, Santos F, Estoup A (2008) Analyzing georeferenced population genetics data with Geneland: a new algorithm to deal with null alleles and a friendly graphical user interface. Bioinformatics 24:1406-1407

$>$ Hedgecock D, Barber PH, Edmands S (2007) Genetic approaches to measuring connectivity. Oceanography (Wash DC) 20(3):70-79

$>$ Hedrick PW (2005) A standardized genetic differentiation measure. Evolution 59:1633-1638

> Hilborn R, Stokes K, Maguire JJ, Smith T and others (2004) When can marine reserves improve fisheries management? Ocean Coast Manag 47:197-205

Hubisz MJ, Falush D, Stephens M, Pritchard JK (2009) Inferring weak population structure with the assistance of sample group information. Mol Ecol Resour 9:1322-1332

Jones GP, Srinivasan M, Almany GR (2007) Population connectivity and conservation of marine biodiversity. Oceanography (Wash DC) 20(3):100-111

Jost L (2008) $G_{\text {st }}$ and its relatives do not measure differentiation. Mol Ecol 17:4015-4026

Kenchington EL, Patwary MU, Zouros E, Bird CJ (2006) Genetic differentiation in relation to marine landscape in a broadcast-spawning bivalve mollusc (Placopecten magellanicus). Mol Ecol 15:1781-1796

Kochergin VP (1987) Three-dimensional prognostic models. In: Heaps NS (ed) Three-dimensional coastal ocean models. American Geophysical Union, Washington, DC, p 201-208

Largier JL (2003) Considerations in estimating larval dispersal distances from oceanographic data. Ecol Appl 13: 71-89

Latch EK, Dharmarajan G, Glaubitz JC, Rhodes OE (2006) Relative performance of Bayesian clustering software for inferring population substructure and individual assignment at low levels of population differentiation. Conserv Genet 7:295-302

- Lester SE, Halpern BS, Grorud-Colvert K, Lubchenco J and others (2009) Biological effects within no-take marine reserves: a global synthesis. Mar Ecol Prog Ser 384: $33-46$

Lipcius RN, Crowder LB, Morgan LE (2005) Metapopulation structure and marine reserves. In: Norse E, Crowder L (eds) Marine conservation biology: the science of maintaining the sea's biodiversity, Vol 19. Island Press, Washington, DC, p 328-345

> Lowe WH, Allendorf FW (2010) What can genetic tell us about population connectivity? Mol Ecol 19:3038-3051

> Marinone SG (2003) A three-dimensional model of the mean and seasonal circulation of the Gulf of California. J Geophys Res 108:3325 
Marinone SG (2008) On the three-dimensional numerical modeling of the deep circulation around Angel de la Guarda Island in the Gulf of California. Estuar Coast Shelf Sci 80:430-434

Marinone SG, Ulloa MJ, Pares-Sierra A, Lavin MF, CudneyBueno R (2008) Connectivity in the northern Gulf of California from particle tracking in a three-dimensional numerical model. J Mar Syst 71:149-158

McQuaid CD, Phillips TE (2000) Limited wind-driven dispersal of intertidal mussel larvae: in situ evidence from the plankton and the spread of the invasive species Mytilus galloprovincialis in South Africa. Mar Ecol Prog Ser 201:211-220

Moreno C, Rojo M, Torre J (2008) Diagnóstico Socioeconómico de la Pesca Artesanal en la Región del Norte del Golfo de California. PANGAS project, Guaymas www. pangas.org/anexos/Appendix-IV.Rapid\%20Appraisal.pdf

Moreno-Báez M, Orr BJ, Cudney-Bueno R, Shaw WW (2010) Using fishers' local knowledge to aid management at regional scales: spatial distribution of small-scale fisheries in the northern Gulf of California, Mexico. Bull Mar Sci 86:339-353

> Munguía-Vega A, Soria G, Pfister T, Cudney-Bueno R (2010) Isolation and characterization of microsatellite loci in the rock scallop (Spondylus calcifer) (Bivalvia: Spondylidae) from the northern Gulf of California, Mexico. Conserv Genet Resour 2:51-54

> Neff BD, Fraser BA (2010) A program to compare genetic differentiation statistics across loci using resampling of individuals and loci. Mol Ecol Resour 10:546-550

Orensanz JM, Parma AM, Turk T, Valero J (2006) Population, dynamics and management of natural scallops. In: Shumway SE, Parsons GJ (eds) Scallops: biology, ecology and aquaculture, Vol 35. Elsevier, Amsterdam, p 765-868

> Palumbi SR (2003) Population genetics, demographic connectivity, and the design of marine reserves. Ecol Appl 13:146-158

Peakall R, Smouse PE (2006) Genalex 6: genetic analysis in Excel. Population genetic software for teaching and research. Mol Ecol Notes 6:288-295

Pelc RA, Baskett ML, Tanci T, Gaines SD, Warner RR (2009) Quantifying larval export from South African marine reserves. Mar Ecol Prog Ser 394:65-78

Pelc RA, Warner RR, Gaines SD, Paris CB (2010) Detecting larval export from marine reserves. Proc Natl Acad Sci USA 107:18266-18271

Pollnac R, Christie P, Cinner JE, Dalton T and others (2010) Marine reserves as linked social-ecological systems. Proc Natl Acad Sci USA 107:18262-18265

Poutiers JM (1995) Bivalvos. In: Fischer W, Krupp F, Schneider W, Sommer C, Carpenter KE, Niem VH (eds) Guía FAO para la identificación de especies para los fines de la pesca: Pacífico centro oriental, Vol 1. Plantas e invertebrados. FAO, Rome

> Pringle JM, Blakeslee AMH, Byers JE, Roman J (2011) Asymmetric dispersal allows an upstream region to control population structure throughout a species' range. Proc Natl Acad Sci USA 108:15288-15293

Pritchard JK, Stephens M, Donnelly P (2000) Inference of population structure using multilocus genotype data. Genetics 155:945-959

Editorial responsibility: Romuald Lipcius, Gloucester Point, Virginia, USA
Proehl JA, Lynch DR, McGillicuddy DJ, Ledwell JR (2005) Modeling turbulent dispersion on the North Flank of Georges Bank using Lagrangian particle methods. Cont Shelf Res 25:875-900

- Rice WR (1989) Analyzing tables of statistical tests. Evolution 43:223-225

> Rossi RE, Mulla DJ, Journel AG, Franz EH (1992) Geostatistical T-tools for modeling and interpreting ecological spatial dependence. Ecol Monogr 62:277-314

Selkoe KA, Watson JR, White C, Horin TB and others (2010) Taking the chaos out of genetic patchiness: seascape genetics reveals ecological and oceanographic drivers of genetic patterns in three temperate reef species. Mol Ecol 19:3708-3726

Shanks AL (2009) Pelagic larval duration and dispersal distance revisited. Biol Bull (Woods Hole) 216:373-385

> Shanks AL, Grantham BA, Carr MH (2003) Propagule dispersal distance and the size and spacing of marine reserves. Ecol Appl 13:159-169

> Siegel DA, Kinlan BP, Gaylord B, Gaines SD (2003) Lagrangian descriptions of marine larval dispersion. Mar Ecol Prog Ser 260:83-96

> Siegel DA, Mitarai S, Costello CJ, Gaines SD, Kendall BE, Warner RR, Winters KB (2008) The stochastic nature of larval connectivity among nearshore marine populations. Proc Natl Acad Sci USA 105:8974-8979

Skoglund C, Mulliner DK (1996) The genus Spondylus (Bivalvia: Spondylidae) of the Panamic Province. The Festivus 28:93-107 www.sandiegoshellclub.com/Prac Festivus.html

Soria G, Tordecillas-Guillen J, Cudney-Bueno R, Shaw W (2010) Spawning induction, fecundity estimation, and larval culture of Spondylus calcifer (Carpenter, 1857) (Bivalvia: Spondylidae). J Shellfish Res 29:143-149

> Sotka EE, Palumbi SR (2006) The use of genetic clines to estimate dispersal distances of marine larvae. Ecology 87:1094-1103

> Treml EA, Halpin PN, Urban DL, Pratson LF (2007) Modeling population connectivity by ocean currents, a graph-theoretic approach for marine conservation. Landscape Ecol 23:19-36

Villalejo-Fuerte M, Arellano-Martínez M, CeballosVázquez BP, García-Domínguez F (2002) Reproductive cycle of Spondylus calcifer Carpenter, 1857 (Bivalvia: Spondylidae) in the 'Bahia de Loreto' National Park, Gulf of California, Mexico. J Shellfish Res 21:103-108

- Visser AW (1997) Using random walk models to simulate the vertical distribution of particles in a turbulent water column. Mar Ecol Prog Ser 158:275-281

> Watson JR, Mitarai S, Siegel DA, Caselle JE, Dong C, McWilliams JC (2010) Realized and potential larval connectivity in the Southern California Bight. Mar Ecol Prog Ser 401:31-48

Werner FE, Cowen RK, Pars CB (2007) Coupled biological and physical models: present capabilities and necessary developments for future studies of population connectivity. Oceanography (Wash DC) 20(3):54-69

> White C, Selkoe KA, Watson JR (2010) Ocean currents help explain population genetic structure. Proc Biol Sci 277: 1685-1694

Wright S (1978) Evolution and the genetics of populations. University of Chicago Press, Chicago, IL

Submitted: March 18, 2011; Accepted: June 6, 2012

Proofs received from author(s): August 21, 2012 